Distribution Categories:

Coal-Based Materials and

Components (UC-114);

Industrial Programs (General)

(UC-310)

ARGONNE NATIONAL LABORATORY

9700 South Cass Avenue, Argonne, Illinois 60439

ANL- $-90 / 17$

ANL-90/17 DE90 018012

\title{
A COMPARATIVE STUDY OF IRON-, NICKEL-, AND COBALT-BASE WELDMENTS EXPOSED IN TVA 20-MW AND ROCKETDYNE ATMOSPHERIC FLUIDIZED BED COMBUSTORS
}

by

D. Y. Wang and K. Natesan

Materials and Components Technology Division

June 1990

Work supported by

U.S. DEPARTMENT OF ENERGY

Office of Conservation and Renewable Energy;

Office of Fossil Energy Advanced Research

and Technology Development Materials Program 


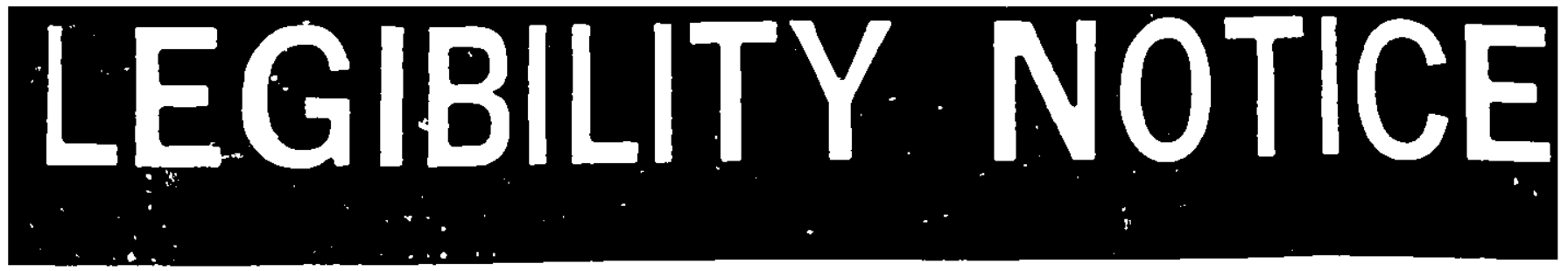

A major purpose of the Technical Information Center is to provide the broadest dissemination possible of information contained in DOE's Research and Development Reports to business, industry, the academic community, and federal, state and local governments.

\section{Although a small portion of this} report is not reproducible, it is being made available to expedite the availability of information on the research discussed herein. 


\section{CONTENTS}

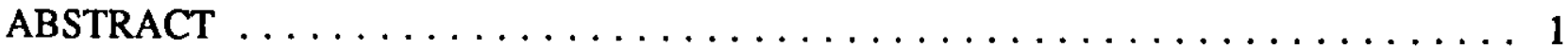

1 INTRODUCTION $\ldots \ldots \ldots \ldots \ldots \ldots \ldots \ldots \ldots \ldots \ldots \ldots$

2 MATERIALS AND EXPERIMENTAL PROCEDURE $\ldots \ldots \ldots \ldots \ldots \ldots 2$

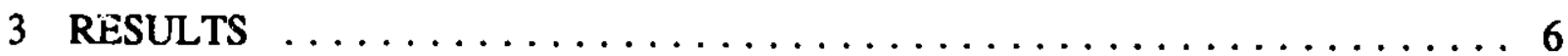

$3.1 \quad$ Base Material: IN800H $\ldots \ldots \ldots \ldots \ldots \ldots \ldots \ldots \ldots \ldots \ldots$

3.2 Filler Materials $\ldots \ldots \ldots \ldots \ldots \ldots \ldots \ldots \ldots \ldots \ldots \ldots \ldots$

3.2.1 Marathon $21 / 33 \ldots \ldots \ldots \ldots \ldots \ldots \ldots \ldots \ldots \ldots \ldots \ldots \ldots \ldots$

3.2.2 Marathon $25 / 35 \ldots \ldots \ldots \ldots \ldots \ldots \ldots \ldots \ldots \ldots$

3.2.3 Marathon $25 / 35 R \ldots \ldots \ldots \ldots \ldots \ldots \ldots \ldots \ldots$

3.2.4 Marathon $30 / 50 \ldots \ldots \ldots \ldots \ldots \ldots \ldots \ldots \ldots \ldots$

3.2.5 Marathon $50 / 50 \mathrm{Nb} \ldots \ldots \ldots \ldots \ldots \ldots \ldots \ldots \ldots \ldots$

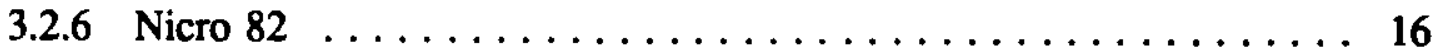

3.2.7 Haynes $188 \ldots \ldots \ldots \ldots \ldots \ldots \ldots \ldots \ldots \ldots \ldots \ldots \ldots 20$

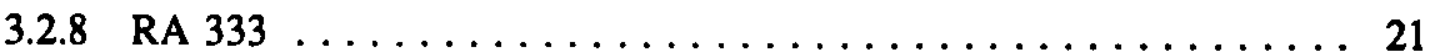

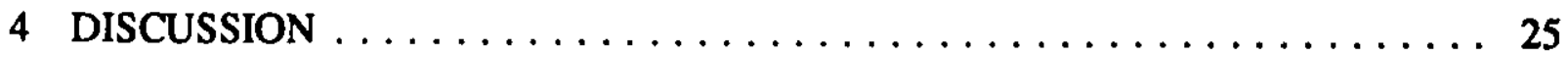

4.1 Corrosion Morphology $\ldots \ldots \ldots \ldots \ldots \ldots \ldots \ldots \ldots \ldots \ldots$

4.2 Effect of Alloy Composition $\ldots \ldots \ldots \ldots \ldots \ldots \ldots \ldots \ldots$

4.3 Hardness Test $\ldots \ldots \ldots \ldots \ldots \ldots \ldots \ldots \ldots \ldots \ldots \ldots \ldots$

$4.4 \mathrm{CaSO}_{4}$ Deposit $\ldots \ldots \ldots \ldots \ldots \ldots \ldots \ldots \ldots \ldots \ldots \ldots$

4.5 Coal/Bed Chemistry $\ldots \ldots \ldots \ldots \ldots \ldots \ldots \ldots \ldots \ldots \ldots \ldots \ldots$

4.6 Heat-Affected Zone $\ldots \ldots \ldots \ldots \ldots \ldots \ldots \ldots \ldots \ldots \ldots \ldots \ldots$ 


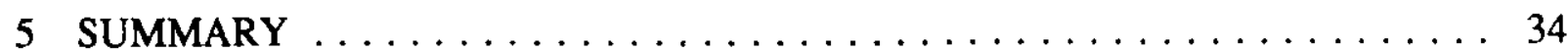

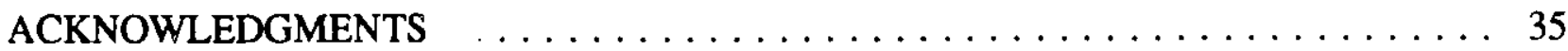

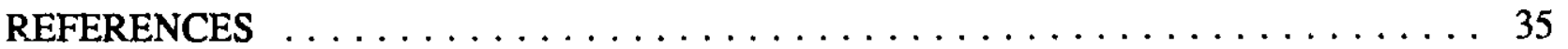

\section{FIGURES}

1 Schematic of Single V-Welded Plate, and Weld Parameters $\ldots \ldots \ldots \ldots \ldots 2$

2 SEM Micrograph and X-ray Mapping of IN800H Exposed in TVA AFBC $\ldots \ldots \ldots 7$

3 SEM Micrograph and X-ray Mapping of IN800H Exposed in Rocketdyne AFBC $\ldots 8$

4 SEM Micrograph and X-ray Mapping of Marathon 21/33 Exposed in TVA AFBC . . 10

5 SEM Micrograph and X-ray Mapping of Marathon 21/33 Exposed in Rocketdyne AFBC $\ldots \ldots \ldots \ldots \ldots \ldots \ldots \ldots \ldots \ldots \ldots \ldots \ldots$

6 SEM Micrograph and X-ray Mapping of Marathon 25/35 Exposed in TVA AFBC . . 12

7 SEM Micrograph and X-ray Mapping of Marathon 25/35 Exposed in

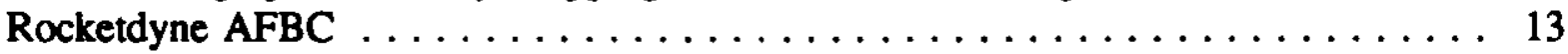

8 SEM Micrograph of Marathon 25/35R Exposed in Rocketdyne AFBC . . . . . . 14

9 SEM Micrograph and X-ray Mapping of Marathon 30/50 Exposed in TVA AFBC . . 15

10 SEM Micrograph and X-ray Mapping of Marathon 30/50 Exposed in Rocketdyne AFBC $\ldots \ldots \ldots \ldots \ldots \ldots \ldots \ldots \ldots \ldots \ldots \ldots \ldots$

11 SEM Micrograph of $50 / 50 \mathrm{Nb}$ Exposed in TVA AFBC $\ldots \ldots \ldots \ldots \ldots \ldots$

12 SEM Micrograph and X-ray Mapping of Marathon 50/50 Nb Exposed in Rocketdyne AFBC . . . . . . . . . . . . . . . . . . . 19

13 SEM Micrograph of Nicro 82 Exposed in TVA AFBC $\ldots \ldots \ldots \ldots \ldots \ldots$

14 SEM Micrograph of Nicro 82 Exposed in Rocketdyne AFBC $\ldots \ldots \ldots \ldots \ldots 21$

15 SEM Micrograph of Haynes 188 Exposed in TVA AFBC $\ldots \ldots \ldots \ldots \ldots \ldots 22$ 
16 Weld Interface between Haynes 188 and RA 333 Exposed in Rocketdyne AFBC . . 22

17 SEM Micrograph and X-ray Mapping of RA 333 Exposed in TVA AFBC . . . . 23

18 SEM Micrograph and X-ray Mapping of RA 333 Exposed in Rocketdyne AFBC . . 24

19 Summary of Corrosion Attack of Weldments: (A) Total Penetration;

(B) Corrosion Attack in TVA AFBC; (C) Corrosion Attack in Rocketdyne AFBC . . 27

20 Pretest Hardness of (A) Marathon 50/50Nb, (B) Marathon 25/35R,

(C) Marathon 25/35, and (D) Nicro $82 \ldots \ldots \ldots \ldots \ldots \ldots \ldots \ldots \ldots$

21 Posttest Hardness of (A) Marathon 50/50Nb, (B) Marathon 25/35R,

(C) Marathon 25/35, (D) Nicro 82, (E) Marathon 21/33, (F) Marathon 30/50,

(G) RA 333, and (H) Haynes 188 in TVA and Rocketdyne AFBCs . . . . . 30

22 Stability Diagram of $\mathrm{CaO}-\mathrm{CaS}-\mathrm{CaSO}_{4}$ System Superimposed on an Oxygen-sulfur Thermochemical Diagram Depicting Regions of Stability of Various Oxide and

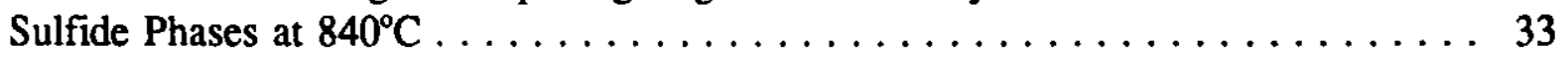

\section{TABLES}

1 Nominal Compositions of Base/Filler Metals (wt.\%) $\ldots \ldots \ldots \ldots \ldots \ldots$

2 Operating Conditions in AFBCs $\ldots \ldots \ldots \ldots \ldots \ldots \ldots \ldots \ldots \ldots \ldots$

3 Chemical Analysis of AFBC Coals $\ldots \ldots \ldots \ldots \ldots \ldots \ldots \ldots \ldots \ldots$

4 Summary of Corrosion Atrack in TVA and Rocketdyne AFBCs . . . . . . . . 26 


\title{
A COMPARATIVE STUDY OF IRON-, NICKEL-, AND COBALT-BASE WELDMENTS EXPOSED IN TVA 20-MW AND ROCKETDYNE ATMOSPHERIC FLUIDIZED BED COMBUSTORS
}

by

D. Y. Wang and K. Natesan

\begin{abstract}
Experimental iron-, nickel-, and cobalt-base weldment materials were exposed in TVA $20-\mathrm{MW}$ and Rocketdyne atmospheric fluidized bed combustors (AFBCs) at $849^{\circ} \mathrm{C}$ for $1261 \mathrm{~h}$ and $871^{\circ} \mathrm{C}$ for $1000 \mathrm{~h}$, respectively. Postexposure analyses were conducted at Argonne National Laboratory. All specimens experienced different degrees of internal oxidation/sulfidation. Among eight filler materials, Marathon 25/35R and Haynes 188 showed the least corrosion attack, i.e., less than $0.5 \mathrm{~mm} / \mathrm{yr}$. A high nickel content in the weldment was unfavorable for corrosion resistance in the AFBC environment. Differences in the coal/bed chemistry of the TVA and Rocketdyne systems yielded different corrosion behavior in the materials. Calcium sulfate deposits on the specimens significantly affected the internal oxidation/sulfidation of the alloys. The results of this study supplement the material data base, in particular that of weldment performance, and aid in materials selection for AFBC applications.
\end{abstract}

\section{INTRODUCTION}

Combustion of coal in a fluidized bed is widely considered to be a viable process for producing electrical power and generating industrial process steam. In contrast to the heat transfer tubes in a conventional pulverized-coal-fired boiler, which are situated only in the freeboard, the tubes in a bubbling bed are present both in the bed and the freeboard above the bed. In power-generating applications, the tubes carry a working fluid, either steam or air, that drives a turbine.

A major material concern in fluidized bed combustion (FBC) systems is the oxidation/sulfidation behavior of the in-bed heat exchanger tube alloys and uncooled structural supports. Over the years, several investigations have evaluated the corrosion/erosion performance of engineering materials. The results of these investigations, assessed in an earlier report, ${ }^{1}$ established that nickel-base alloys, when exposed to FBC environments, can undergo sulfidation attack that leads to catastrophic failure. Further, the corrosion/erosion data show a wide variation in the extent of degradation in specimens exposed in different locations within the same bed, as well as in specimens exposed in different beds with nominally similar environments. Moreover, information on weldment performance is especially lacking, even though the heat exchanger tubes and structural support members must be welded in a shop and/or in the field. The purpose of this study is to evaluate the corrosion/erosion behavior of several experimental filler metals intended for service in an 
purpose, several weldments were fabricated, and specimens of the welded plates were exposed in two atmospheric fluidized bed combustors (AFBCs).

\section{MATERIALS AND EXPERIMENTAL PROCEDURE}

Incoloy $800 \mathrm{H}$ was selected as the base material for weldment evaluation. Eight filler materials containing various amounts of nickel and chromium in the ranges of 22.77 to 71.6 wt.\% and 18.7 to $50 \mathrm{wt} . \%$, respectively, were selected for weldment fabrication. The nominal compositions of the base metal and filler materials are listed in Table 1. Weldment samples were cut from either single or double V-welded plates (Fig. 1), which were certified as to quality by dye-penetrant and radiography techniques. The welded plates were subsequently sliced into 2.5-mm-thick sections, from which weldment coupons were cut for corrosion experiments. Each coupon specimen contained the base metal, the heat-affected zone (HAZ), and the weld metal. The coupons were finely polished with 600-grit $\mathrm{SiC}$ paper and welded onto a corrosion probe. Weldments were tested in an uncooled condition by exposure of the corrosion probe in the AFBCs.

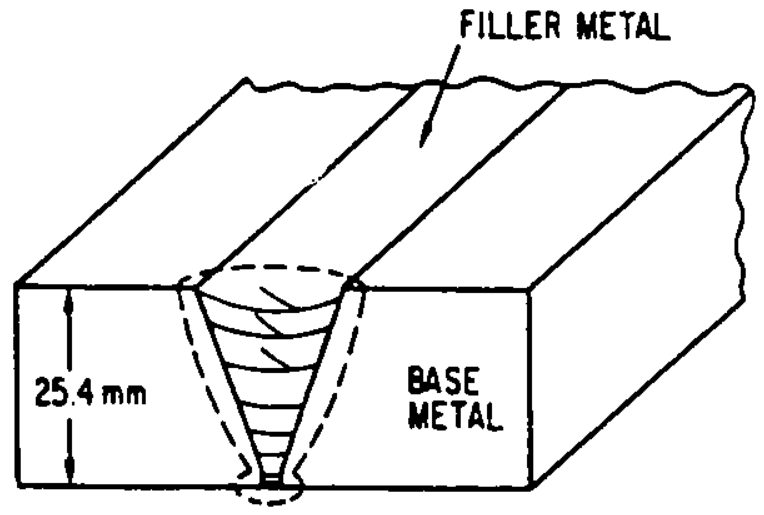

SINGLE $V$

$\begin{array}{ll}\text { Material Preparation: } & \begin{array}{l}\text { Single V } \\ \text { Mill-annealed }\end{array} \\ \text { Heat Treatment: } & \text { SMAW and GMAW } \\ \text { Weld Process: } & \text { Argon 80\%; Helium 20\% } \\ \text { Torch Gas: } & \text { Argon } \\ \text { Backup Gas: } & 10-12 \\ \text { No. of Passes: } & 14 \mathrm{~V} \\ \text { Voltage: } & 160 \mathrm{~A} \\ \text { Current: } & 2.3 \text { to } 3.0 \mathrm{~mm} / \mathrm{s} \\ \text { Travel Speed: } & 9.5 \text { to } 12.7 \mathrm{~mm} \\ \text { Tip Gap: } & \text { Dye Penetrant, X-radiography } \\ \text { Weld Check: } & \end{array}$

Fig. 1. Schematic of Single V-Welded Plate, and Weld Parameters 
Table 1. Nominal Compositions of Base/Filler Metals (wt.\%)

\begin{tabular}{|c|c|c|c|c|c|c|c|c|c|c|c|}
\hline Metal & C & $\mathrm{Cr}$ & $\mathrm{Ni}$ & $\mathrm{Fe}$ & Co & Mn & $\mathrm{Si}$ & Mo & $S$ & $\mathbf{N}$ & Others \\
\hline IN800H & 0.07 & 21.12 & 33.1 & 43.2 & 0.0 & 0.8 & 0.34 & 0.0 & 0.0 & 0.0 & $\mathrm{Cu} 0.15$, Ti $0.46 \mathrm{Al} 0.3$ \\
\hline Nicro 82 & 0.02 & 18.70 & Bal. & 2.74 & 0.0 & 3.9 & 0.3 & 0.68 & 0.0 & 0.0 & $\mathrm{Nb} / \mathrm{Ta} 2.0$, Ti 0.07 \\
\hline Alloy" $21 / 33$ & 0.19 & 22.20 & 33.2 & Bal. & 0.0 & 1.58 & 0.35 & 0.0 & 0.004 & 0.05 & $\mathrm{Nb} / \mathrm{Ta} 2.49$ \\
\hline Alloy $25 / 35$ & 0.41 & 25.40 & 34.8 & Bal. & 0.0 & 1.9 & 0.91 & 0.3 & 0.006 & 0.08 & -- \\
\hline Alloy 25/35R & 0.42 & 26.30 & 35.3 & Bal. & 0.0 & 1.76 & 1.06 & 0.0 & 0.05 & 0.0 & Nb 1.35 \\
\hline Alloy $30 / 50$ & 0.51 & 28.80 & 47.6 & Bal. & 0.0 & 2.24 & 1.56 & 0.0 & 0.009 & 0.0 & W 4.61 \\
\hline Alloy $50 / 50 \mathrm{Nb}$ & 0.06 & 50.00 & 48.0 & 0.8 & 0.0 & 1.0 & 0.6 & 0.0 & 0.015 & 0.15 & $\mathrm{Nb} 1.75$ \\
\hline Haynes 188 & 0.10 & 22.17 & 22.8 & 1.67 & Bal. & 0.81 & 0.38 & 0.0 & 0.0 & 0.0 & W 13.56 \\
\hline RA 188 & 0.06 & 24.96 & 46.2 & Bal. & 3.06 & 1.58 & 0.88 & 3.34 & 0.002 & 0.0 & W $3.06, \mathrm{Cu} 0.16$ \\
\hline
\end{tabular}

- Marathon Specialty Alloys. 
Weldment corrosion probes were prepared for exposure in two AFBC test facilities, namely, the Tennessee Valley Authority (TVA) 20-MW pilot plant and Rockwell International's Rocketdyne Division combustor. The TVA pilot plant has a flexible feed system that allows underbed and overbed feeding. The base configuration is for underbed feeding of coal and limestone to the boiler in a semidense, pneumatic feed system. During the exposure period, low- chlorine Warrior coal was fed from under the bed (for $377 \mathrm{~h}$ ) and, subsequently, Sarpy Creek coal was fed from under the bed (for $432 \mathrm{~h}$ ) and over the bed (for $452 \mathrm{~h}$ ). Material collected in the cyclone hoppers was recycled through a set of underbed ports. There were three different types of bubble caps, each providing different air flow patterns to promote mixing of solids and eliminate localized reducing zones. The underbed coal and limestone feed points, recycle feed points, and bed ash drain points penetrate the furnace floor, which served as the air distributor plate for the AFBC.

The Rocketdyne facility, a $6 \times 6$-ft AFBC, was operated in the bubbling mode with Illinois \#6 coal throughout the 1000-h exposure. The combustor was cooled by compressed air flowing through a full-scale tube bank. Air from an auxiliary compressor and preheater was supplied to the top of the combustor tower at $219^{\circ} \mathrm{C}$, continued down to the in-bed bank for final heating, and then was discharged into the atmosphere at $871^{\circ} \mathrm{C}$. Test specimens were built into the in-bed tube bundle and exposed to bed temperatures of $482-871^{\circ} \mathrm{C}$. The coal, limestone, and ash collection-rejection systems delivered solids into the combustor. Spent bed material, largely calcium sulfate, was drained from the bottom of the bed into collection barrels for disposal. The operating conditions are summarized in Table 2 for both AFBC test facilities. Details of the design and operational features for the TVA and Rocketdyne AFBCs are well documented elsewhere. ${ }^{2,3}$ Chemical compositions of the coals used in the two facilities are listed in Table 3.

Comparative hardness measurements were made with a Leitz Durimet small hardness tester before and after the AFBC exposure. The hardness data were obtained for depths up to $600 \mu \mathrm{m}$ from the weld interface in either direction. After exposure, the weldment samples were first examined by optical microscope for metallographical variation. Subsequently, weldment cross-sections were mounted and polished for analysis by scanning electron microscope (SEM). A JSM-840A SEM, equipped with an energy-dispersive X-ray spectrometer (EDS) and a wavelength-dispersive X-ray spectrometer (WDS), was used for morphological and chemical analyses. The chemical products of reaction betweon sulfate deposits and the weldment constituents were studied on a Harrop-726 differential thermal analyzer (DTA). Heating and cooling curves of the $\mathrm{CaO} / \mathrm{Cr}_{2} \mathrm{O}_{3}$ mixture and $\mathrm{CaSO}_{4} 2 \mathrm{H}_{2} \mathrm{w}$ mixed with iron, chromium, and nickel, respectively, were monitored against an $\mathrm{Al}_{2} \mathrm{O}_{3}$ standard over a temperature range of 25 to $1200^{\circ} \mathrm{C}$. A GE-700 X-ray diffractometer was used for phase identification. 
Table 2. Operating Conditions in AFBCs

\begin{tabular}{lll}
\hline Parameters & TVA & Rocketdyne \\
\hline Fluidized Bed Temperature $\left({ }^{\circ} \mathrm{C}\right)$ & 849 & 871 \\
Fluidized Bed Height $(\mathrm{m})$ & 1.14 & 2.41 \\
Fluidized Bed Superficial Velocity $(\mathrm{m} / \mathrm{s})$ & 2.4 & 1.52 \\
Coal Type & Warrior & Illinois \#6 \\
& Sarpy Creek & \\
Coal Size (mm) & $7.9-31.7$ & 10 \\
Limestone Size $(\mathrm{nim})$ & 3.2 & 1.6 \\
Exposure Time $(\mathrm{h})$ & 1261 & 1000 \\
\hline
\end{tabular}

Table 3. Chemical Analysis of AFBC Coals

\begin{tabular}{lccc}
\hline Analysis & Warrior & Sarpy Creek & Illinois \#6 \\
\hline Proximate Analysis & & & \\
Moisture (\%) & 5.7 & 18.2 & 9.46 \\
Ash (\%) & 13.5 & 7.9 & 9.26 \\
Volatile Matter (\%) & 35.6 & 28.7 & 36.48 \\
Fixed Carbon (\%) & 45.4 & 45.0 & 44.77 \\
Heating Value (Btu/lb) & 11000 & 6000 & 10903 \\
& & & \\
Ultimate Analysis & & & \\
C & 67.8 & 54.6 & 62.2 \\
H & 4.6 & 4.6 & 4.18 \\
N & 1.6 & 1.4 & 1.15 \\
S & 4.9 & 0.6 & 3.27 \\
Cl & 0.03 & 0.01 & 0.0 \\
\hline
\end{tabular}




\section{RESULTS}

The variations in AFBC operating conditions, coal/bed chemistry, and alloying elements resulted in differences in corrosion behavior of the various filler materials exposed in the two test facilities. Results of the morphological and analytical examinations are summarized below.

\subsection{BASE MATERIAL: IN800H}

An external oxide scale developed on the IN800H base material exposed in the TVA AFBC environment. However, internal oxidation, especially along grain boundaries, was also observed (Fig. 2). The EDS/WDS X-ray mapping shows sulfur scattered along grain boundary oxides. After the 1251-h exposure in the TVA facility, a loose oxide scale $\approx 20 \mu \mathrm{m}$ thick, was observed on the specimen surface. The scale consisted of an inner $\mathrm{Cr}_{2} \mathrm{O}_{3}$ layer $(\approx$ $5 \mu \mathrm{m}$ thick) and an outer iron oxide layer mixed with $\mathrm{CaSO}_{4}$. Chromium oxide formed primarily along grain boundaries as a result of oxygen penetration. Dilution of chromium in the vicinity of grain boundaries was observed in the $\mathrm{X}$-ray map. In the substrate matrix, $\mathrm{Cr}_{\mathrm{x}} \mathrm{S}$ was observed in the form of scattered sulfide particles. The internal attack reached about 250 $\mu \mathrm{m}$ into the substrate material.

The IN800H specimen exposed in the Rocketdyne AFBC experienced much less corrosion attack. A uniform $\mathrm{Cr}_{2} \mathrm{O}_{3}$ scale, 3-5 $\mu \mathrm{m}$ thick, formed on the specimen surface (Fig. 3). As in the samples exposed in the TVA facility, the oxide scale formed in the Rocketdyne AFBC was covered by a layer (but somewhat thinner) of $\mathrm{CaSO}_{4}$. The underlying materials remained mostly intact, except that a few small scattered oxides and MnS particles were observed in the substrate matrix. The maximum observed ccrrosion penetration was $50 \mu \mathrm{m}$ from the specimen surface.

\subsection{FILLER MATERIALS}

Chromium provides superior corrosion resistance to materials used in high-temperature, nultiple-oxidant environments such as coal gasification and fluidized bed combustors. ${ }^{\text {is }}$ Because of their high chromium content, several commercial filler materials, including Marathon specialty alloys and other cobalt- and iron-base alloys, were selected for evaluation in AFBC environments. The results of the postexposure analyses were used to quantify the relationship betiveen alloy composition and corrosion performance.

\subsubsection{Marathon 21/33}

Marathon 21/33, containing $22.2 \mathrm{wt} . \% \mathrm{Cr}$ and $33 \mathrm{wt} . \% \mathrm{Ni}$, revealed a complex scale morphology after a 1261-h exposure in the TVA AFBC facility, as shown in Fig. 4. The corrosion behavior of Marathon 21/33 was similar to that of $\mathrm{IN} 800 \mathrm{H}$, but the extent of internal attack was less. A nonuniform, 5- $\mu \mathrm{m}$-thick $\mathrm{Cr}_{2} \mathrm{O}_{3}$ scale developed between the substrate material and a 30- $\mu \mathrm{m}$-thick external iron oxide scale. The iron oxide scale seemed highly porous and exhibited several cracks. The outer surface of iron oxide scale was 

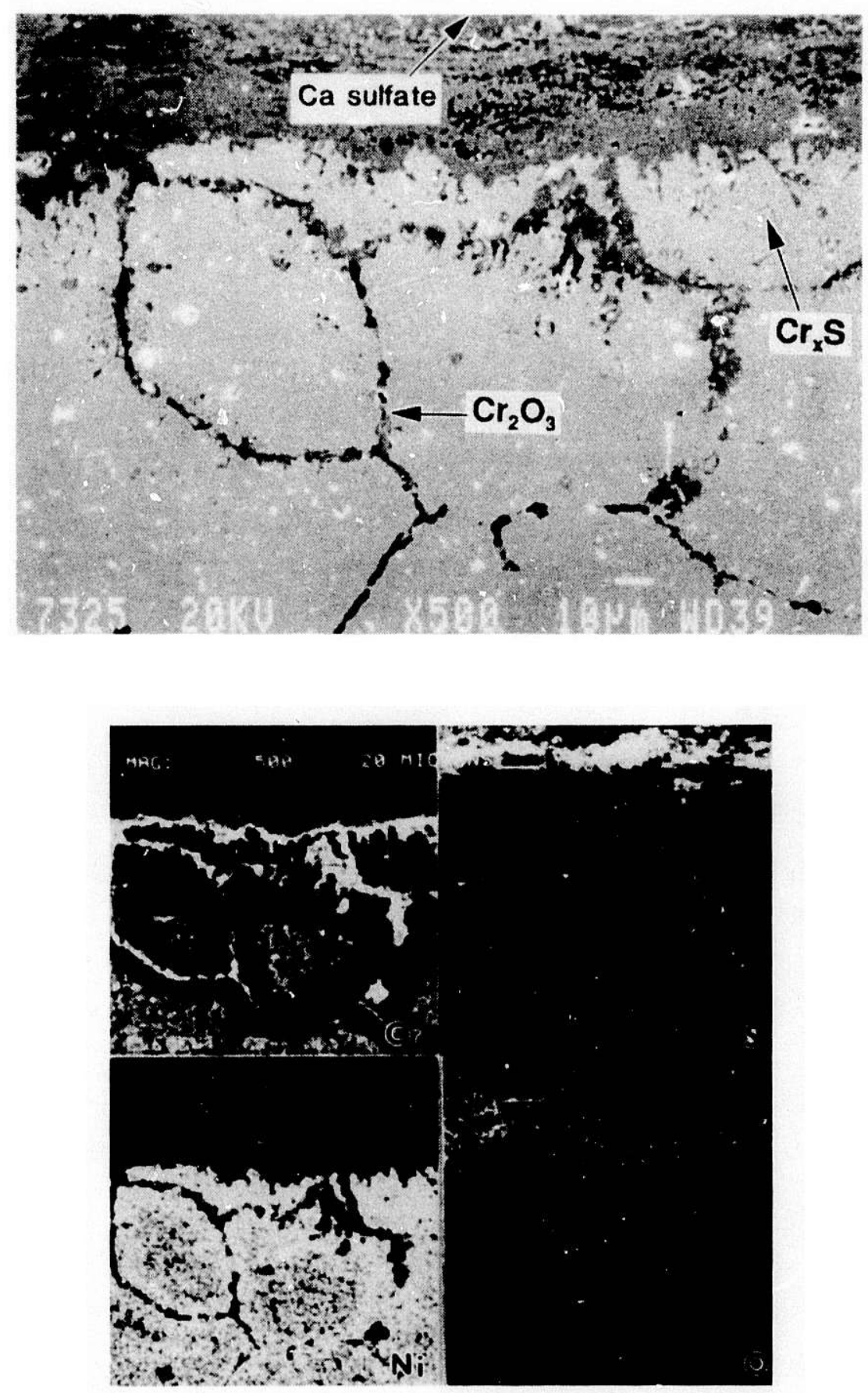

Fig. 2. SEM Micrograph and X-ray Mapping of IN800H Exposed in TVA AFBC 

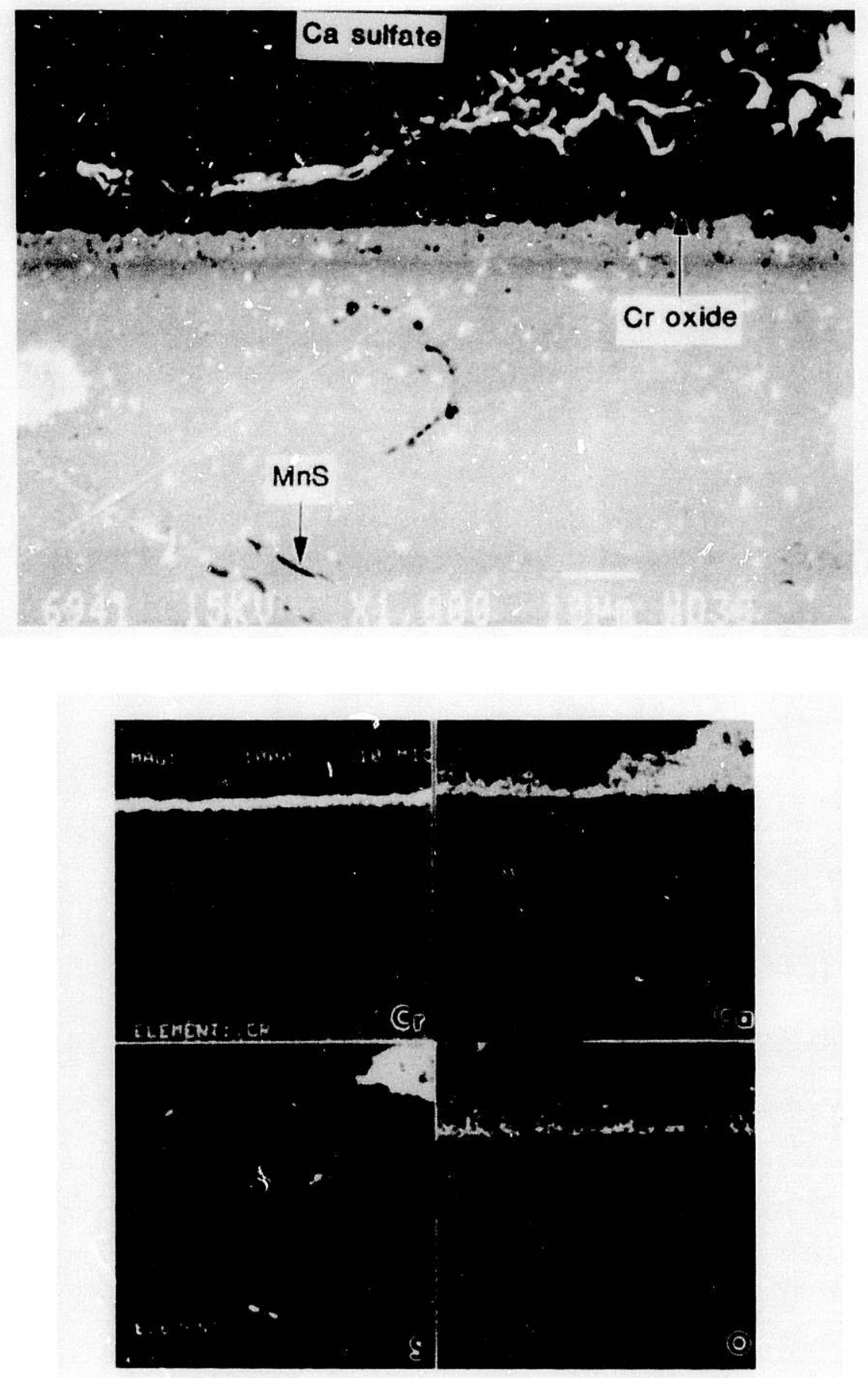

Fig. 3. SEM Micrograph and X-ray Mapping of IN800H Exposed in Rocketdyne AFBC 
covered with a layer $\left(\approx 15 \mu \mathrm{m}\right.$ thick) of $\mathrm{CaSO}_{4}$. The deposit also penetrated through pores and cracks in the scale and contacted the substrate alloy. Both internal oxidation and sulfidation were observed in Marathon 21/33 after exposure to FBC. Corrosion products such as $\mathrm{Cr}_{\mathrm{x}} \mathrm{S}, \mathrm{MnS}, \mathrm{NbS}, \mathrm{Cr}_{2} \mathrm{O}_{3}$, and $\mathrm{SiO}_{2}$ were identified in the substrate matrix by EDS/WDS analyses. The depth of internal oxidation/sulfidation penetration was $\approx 90 \mu \mathrm{m}$.

Marathon 21/33 exposed in the Rocketdyne AFBC exhibited better corrosion performance than that exposed in the TVA facility (Fig. 5). A significant difference in the corrosion morphology between the two specimens is the absence of iron oxide in the external scale in the Rocketdyne-exposed specimen. Instead, a 5- $\mu$ m-thick $\mathrm{Cr}_{2} \mathrm{O}_{3}$ scale developed on the specimen surface between the substrate and sulfate deposit. The oxide layer was continuous and uniform. A few internal precipitates, primarily $\mathrm{MnS}, \mathrm{NbS}$, and $\mathrm{Cr}_{\mathrm{x}} \mathrm{S} / \mathrm{Cr}_{2} \mathrm{O}_{3}$, were observed in the substrate. The depth of internal oxidation/sulfidation was limited to $50 \mu \mathrm{m}$ from the surface. The specimen surface was covered with $\mathrm{CaSO}_{4}$ deposit, as was the sample exposed in the TVA facility. However, the thickness of the deposition on the Rocketdyne specimen was $\approx 2-3 \mu \mathrm{m}$.

\subsubsection{Marathon 25/35}

Marathon 25/35, containing $25 \mathrm{wt} . \% \mathrm{Cr}$ and $35 \mathrm{wt}$ \% $\mathrm{Ni}$, was severely corroded in the TVA combustor. The sample surface was covered with a thick layer of $\mathrm{CaSO}_{4}$, beneath which was a thick layer of porous iron oxide. As shown in Fig. 6, a thin layer of $\mathrm{Cr}_{2} \mathrm{O}_{3}$ formed between the external iron oxide and the substrate. However, the oxide layer at the surface was discontinuous and could not protect the underlying metal from corrosion. Significant amounts of $\mathrm{Cr}_{2} \mathrm{O}_{3}$ extended along grain boundaries into the substrate and formed a network of internal attack to a depth of $140 \mu \mathrm{m}$. In addition, $\mathrm{SiO}_{2}$ was observed along grain boundaries in association with chromium oxide. The EDS mapping (see Fig. 6) showed scattered sulfate particles within the attacked region. Penetration of the combustor deposit into the substrate was observed. Calcium sulfide and/or oxide were identified primarily along the area of internal oxidation/sulfidation. The deepest penetration of calcium-containing phases was 30 $\mu \mathrm{m}$ from the substrate/oxide interface.

Corrosion attack on Marathon 25/35 in the Rocketdyne AFBC appeared to be less severe than in the TVA facility. A uniform layer of $\mathrm{Cr}_{2} \mathrm{O}_{3}$ scale formed on the sample surface in the Rocketdyne AFBC, and the extent of internal attack was blocked largely by the oxide scale. Localized penetration of oxygen and sulfur was observed (see Fig. 7) at the interface between the oxide scale and the substrate, extending $\approx 30 \mu \mathrm{m}$ into the substrate. Large discrete particles of $\mathrm{SiO}_{2}$ formed along the oxide/substrate interface. In addition, $\mathrm{SiO}_{2}$ phase was present along the internal $\mathrm{Cr}_{2} \mathrm{O}_{3}$ phases in the substrate alloy. A few $\mathrm{MnS}$ particles, $1 \mu \mathrm{m}$ in diameter, were identified $\approx 50 \mu \mathrm{m}$ from the surface. Very little $\mathrm{CaSO}_{4}$ deposit was discovered on the exposed specimen. 

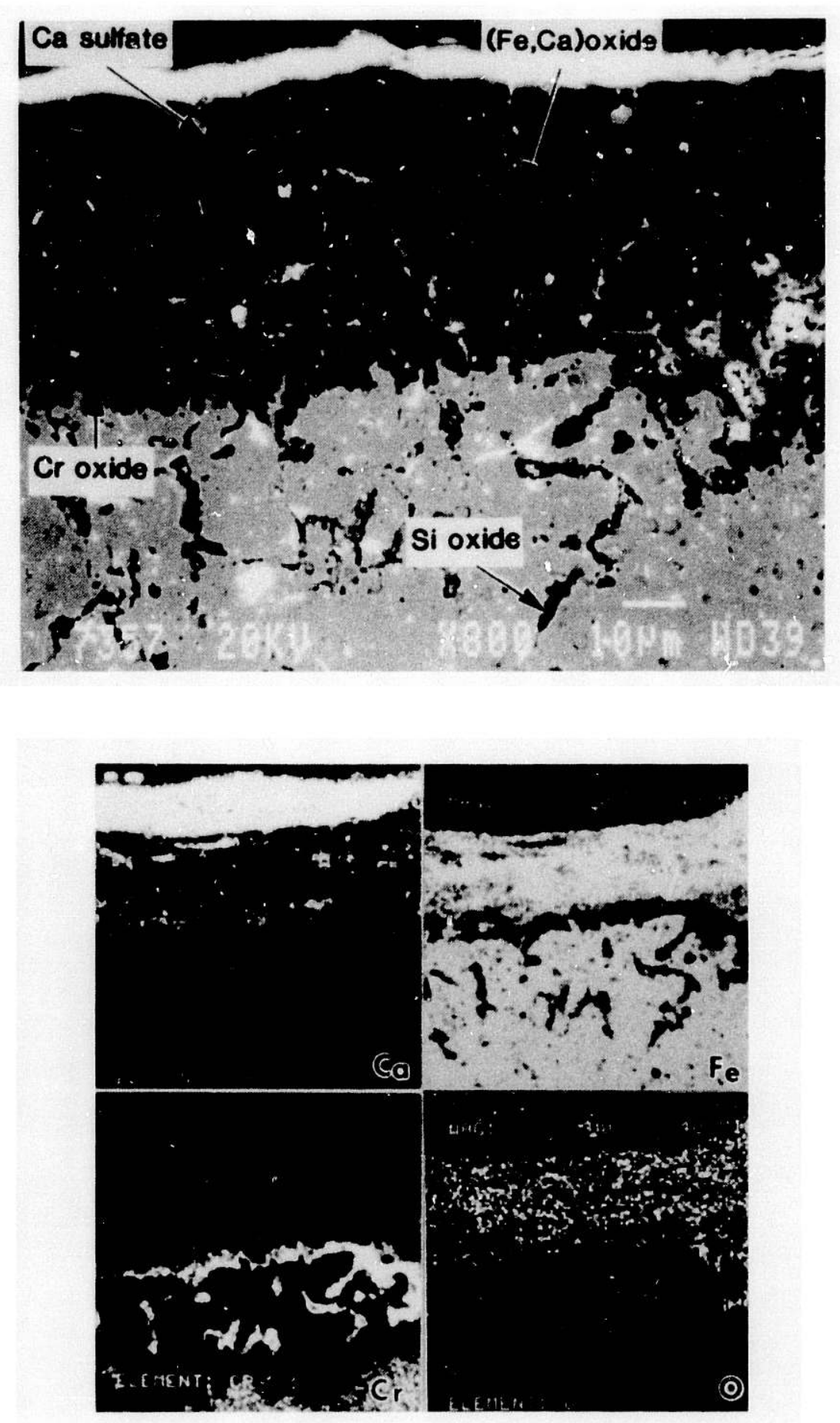

Fig. 4. SEM Micrograph and X-ray Mapping of Marathon 21/33 Exposed in TVA AFBC 

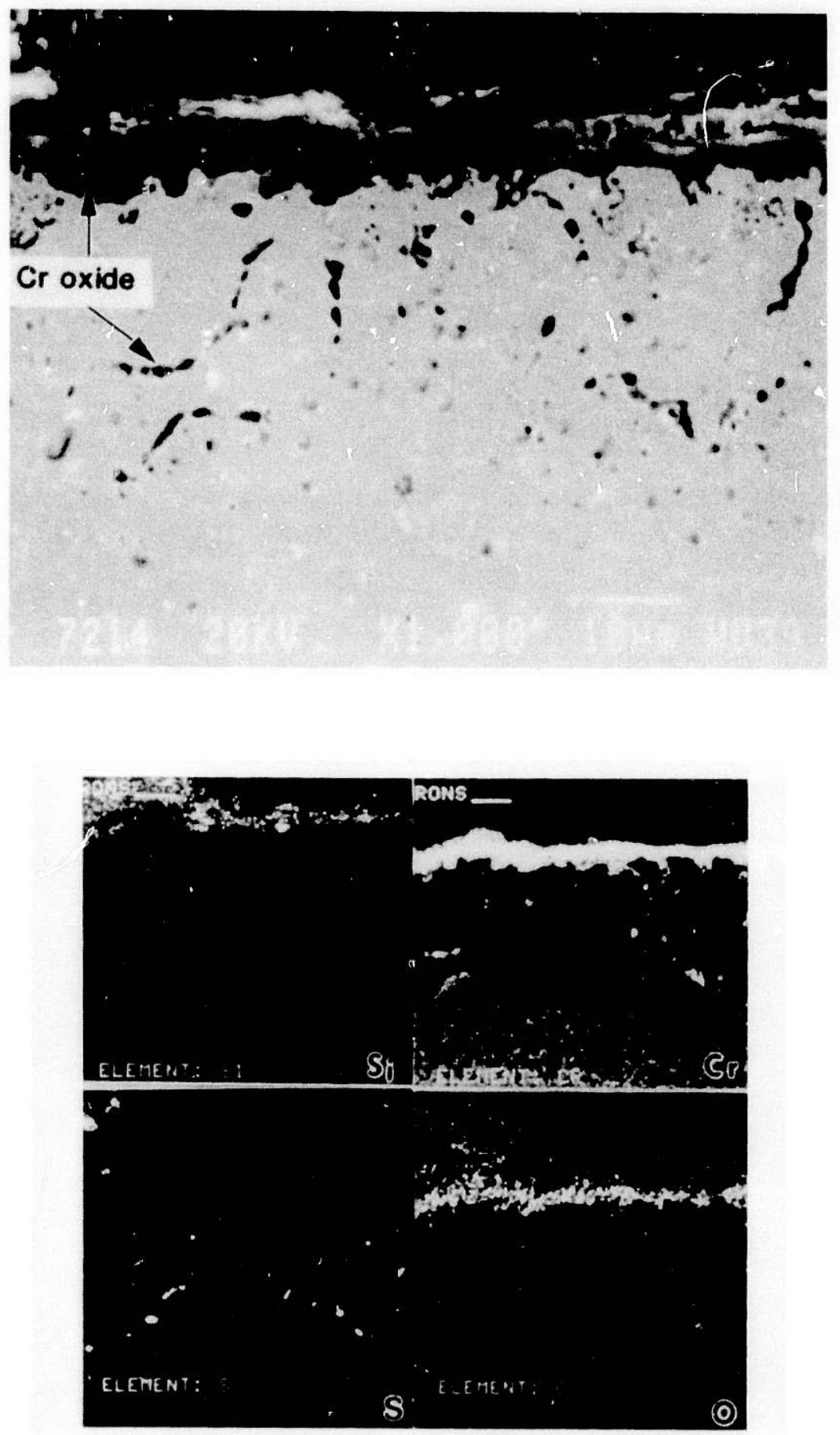

Fig. 5. SEM Micrograph and X-ray Mapping of Marathon 21/33 Exposed in Rocketdyne AFBC 

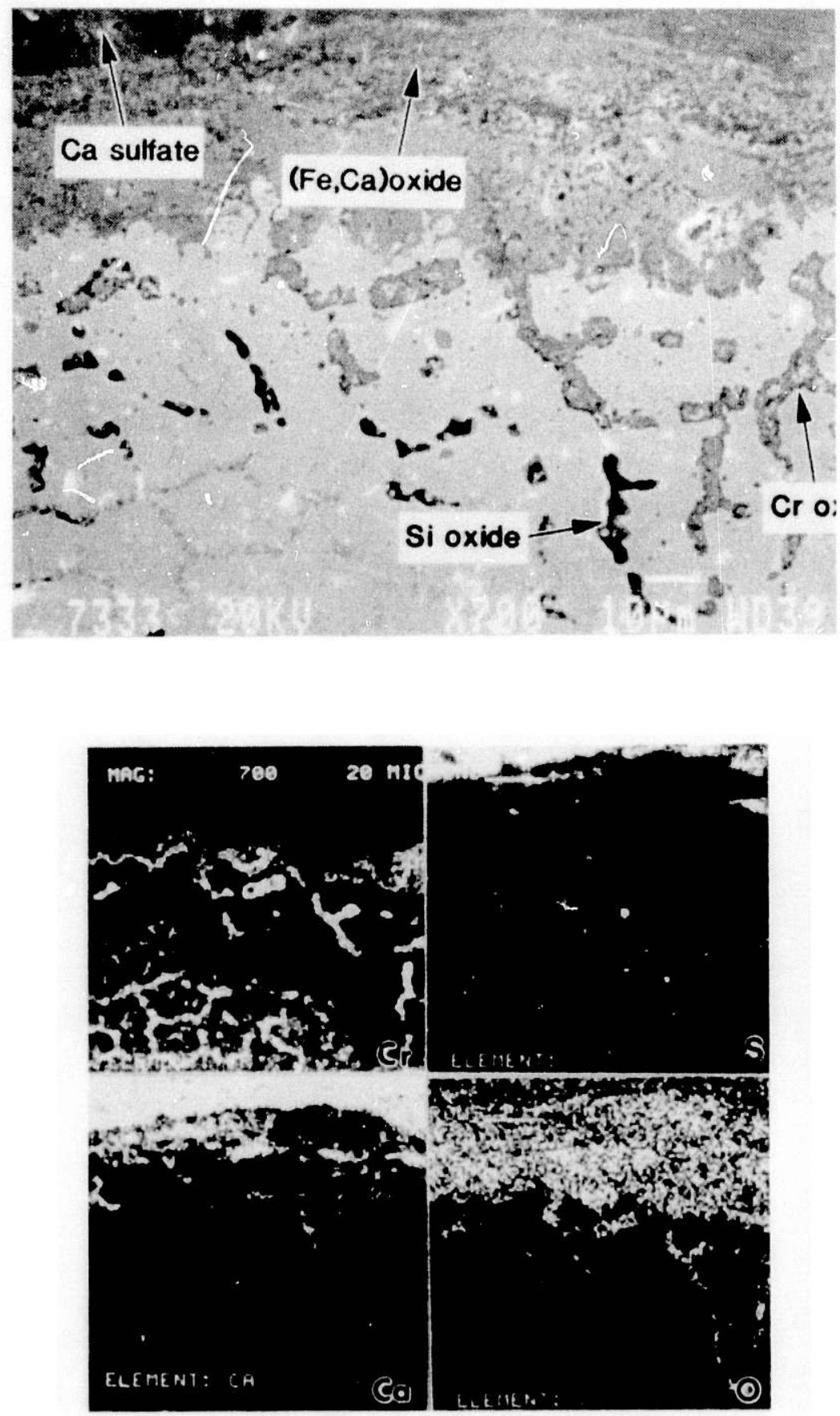

Fig. 6. SEM Micrograph and X-ray Mapping of Marathon 25/35 Exposed in TVA AFBC 

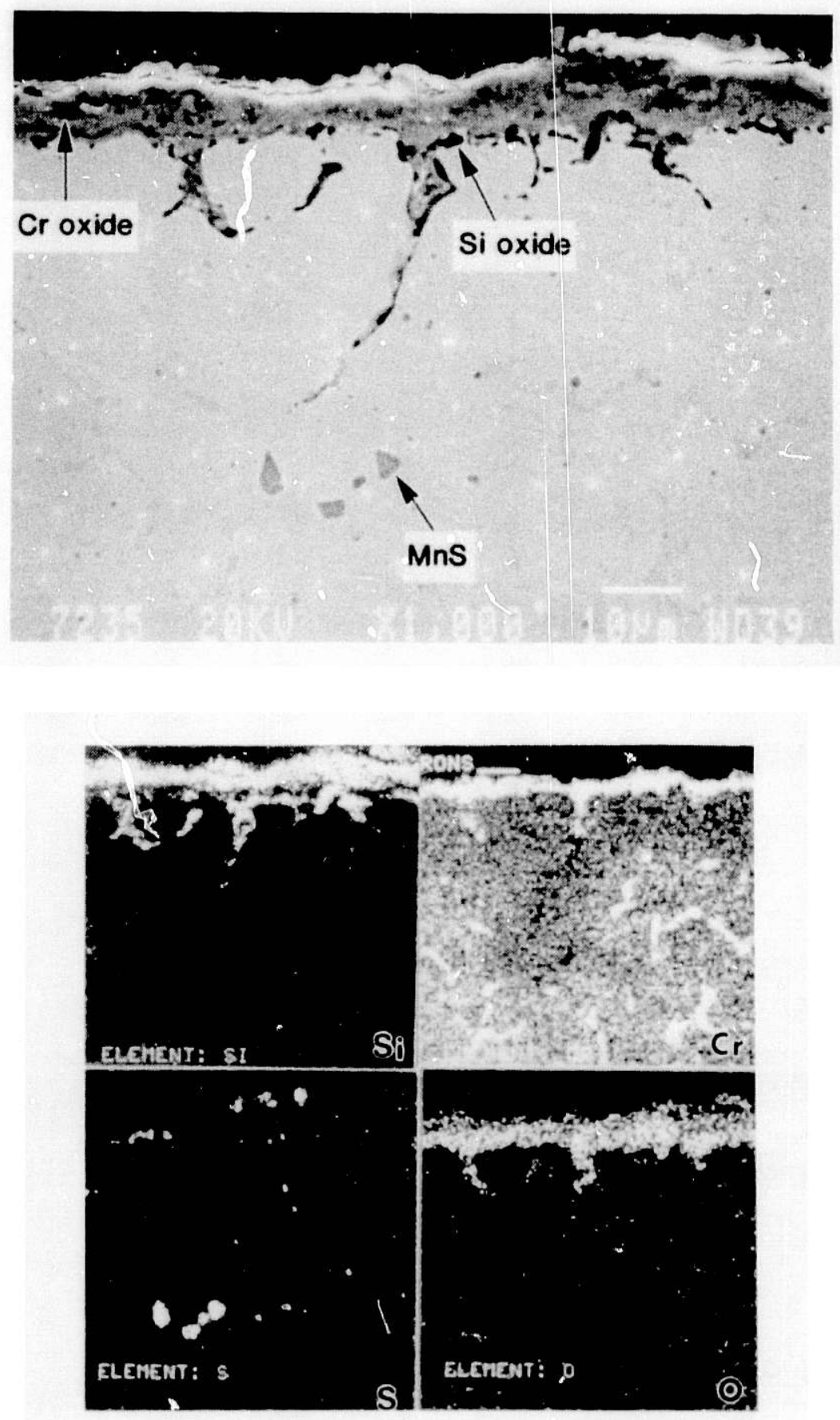

Fig. 7. SEM Micrograph and X-ray Mapping of Marathon 25/35 Exposed in Rocketdyne AFBC 


\subsubsection{Marathon 25/35R}

Marathon 25/35R, containing $1.35 \mathrm{wt} . \% \mathrm{Nb}$, is a $\mathrm{Nb}$-modified version of Marathon 25/35. Due to the limited rack capacity of the TVA combustor, Marathon 25/35R was exposed only in the Rocketdyne facility. The concsion performance of Marathon 25/35R in the Rocketdyne AFBC was rated as the best among all the filler materials exposed in either facility. The weldment surface was covered with a continuous 3-5- $\mu$ m-thick $\mathrm{Cr}_{2} \mathrm{O}_{3}$ film that successfully blocked further penetration of oxygen or sulfur into the substrate material, as can been seen in Fig. 8. Internal oxidation of chromium in the substrate was not observed. Several isolated MnS particles were scattered in the substrate matrix, but these were inclusions in the weldment and had not developed during exposure to FBC atmospheres.

\subsubsection{Marathon 30/50}

Marathon 30/50, containing $29 \mathrm{wt} . \% \mathrm{Cr}$ and $48 \mathrm{wt} . \% \mathrm{Ni}$, experienced massive breakaway corrosion attack when exposed in the TVA combustor. Severe scaling and internal oxidation/sulfidation occurred during the exposure, as shown in Fig. 9. A 100- $\mu \mathrm{m}$-thick bulky scale, composed of a mixture of $\mathrm{Cr}_{2} \mathrm{O}_{3}$, iron oxide, and $\mathrm{SiO}_{2}$, was observed. As in the Marathon 25/35 exposed in the TVA facility, a significant amount of $\mathrm{CaSO}_{4}$ was mixed within the oxide scale. $\mathrm{A}_{\mathrm{Cr}} \mathrm{O}_{3}$ phase that formed between the external oxide scale and the substrate was disrupted in many locations. Severe internal oxidation/sulfidation was initiated at the point where the discontinuity occurred. Internal oxidation, primarily $\mathrm{Cr}_{2} \mathrm{O}_{3}$, extended from the scale/metal interface into the substrate. Sulfide particles were distributed in the metal matrix. The depth of maximum internal attack reached $\approx 250 \mu \mathrm{m}$ from the surface.

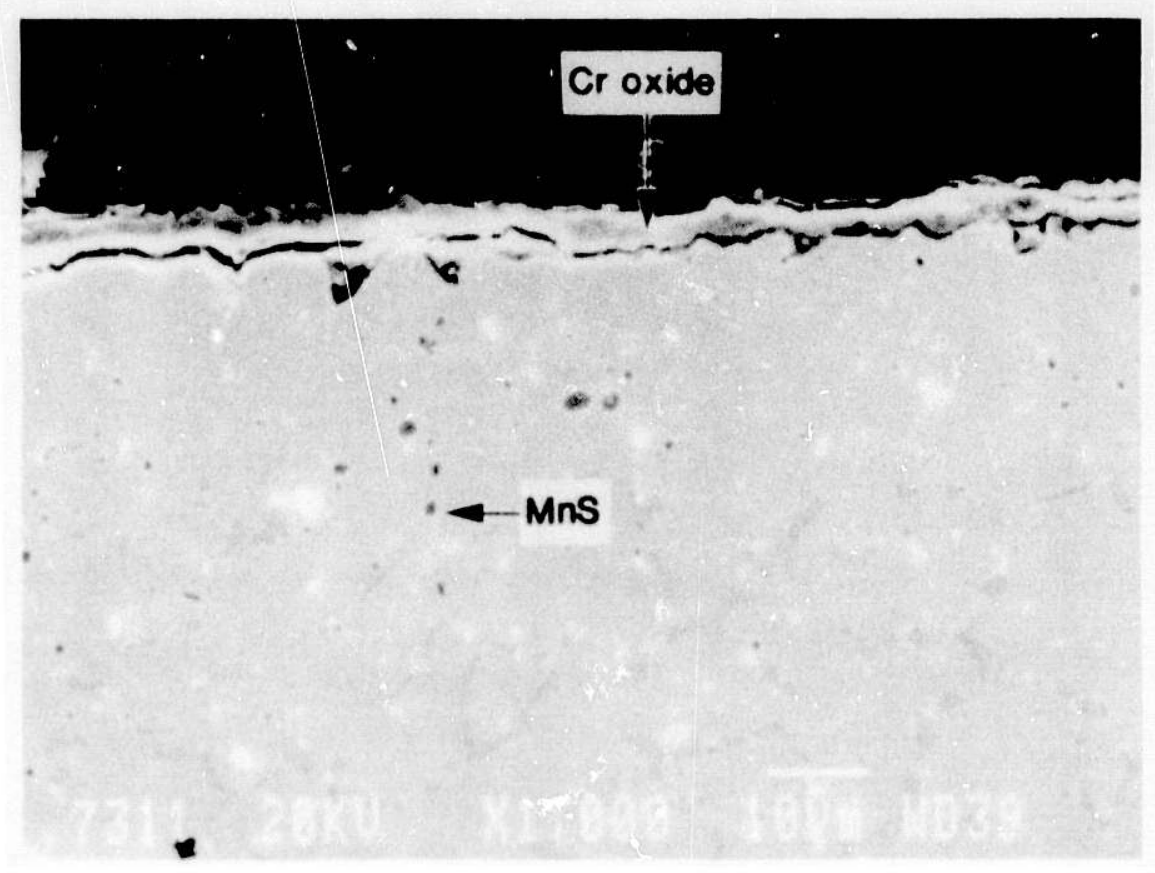

Fig. 8. SEM Micrograph of Marathon 25/35R Exposed in Rocketdyne AFBC 

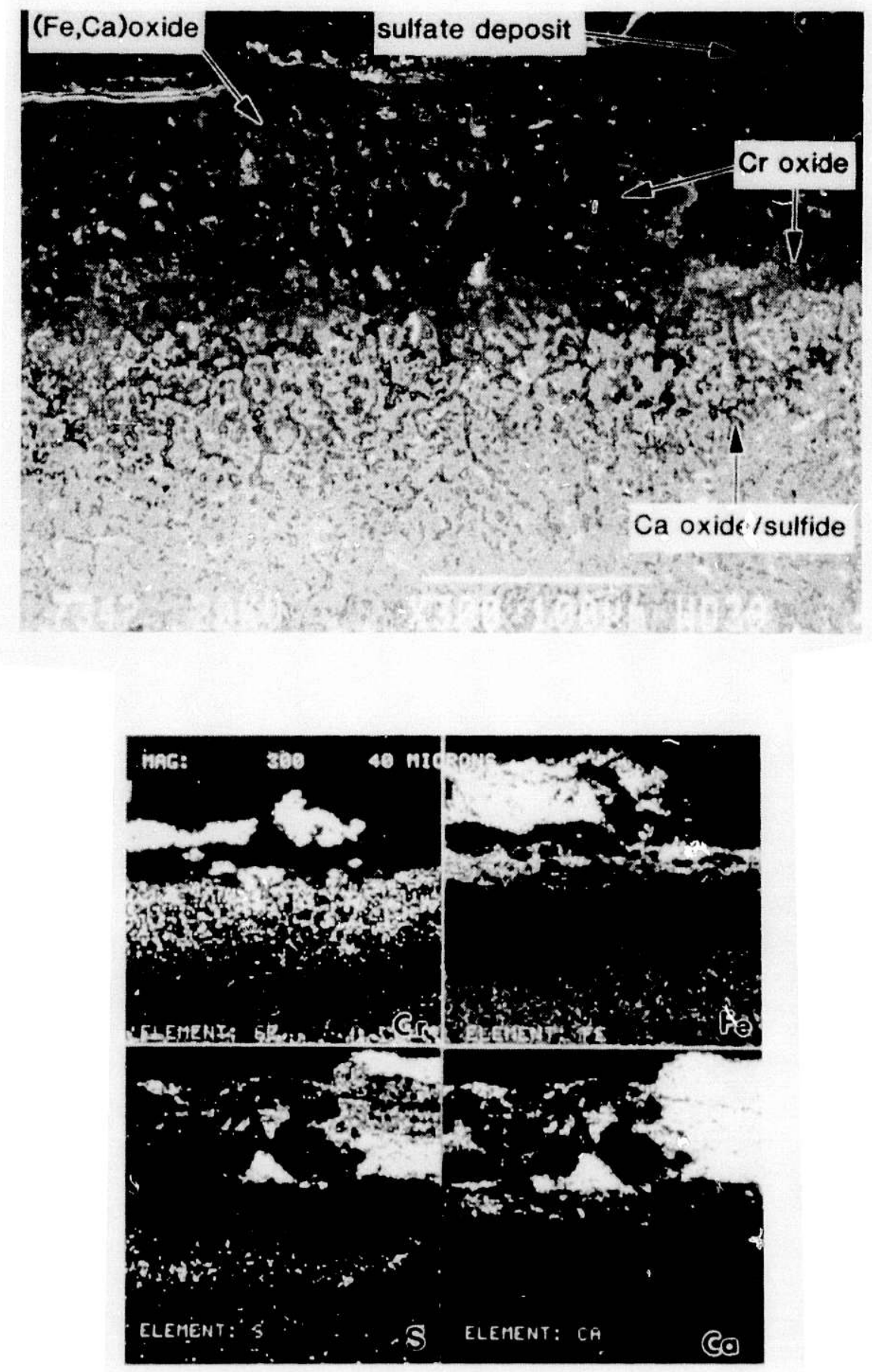

Fig. 9. SEM Micrograph and X-ray Mapping of Marathon 30/50 Exposed in TVA AFBC 
Marathon 30/50 exposed in the Rocketdyne AFBC also experienced localized internal oxidation and sulfidation, as shown in Fig. 10. The sample was covered with a 5- $\mu \mathrm{m}$-thick $\mathrm{CaSO}_{4}$ deposit. A 5- $\mu$ m-thick $\mathrm{Cr}_{2} \mathrm{O}_{3}$ scale formed between the sulfate deposit and the substrate ailoy. As in the Marathon 25/35 exposed in the Rocketdyne combustor, massive amounts of $\mathrm{SiO}_{2}$ were observed beneath the $\mathrm{Cr}_{2} \mathrm{O}_{3}$ layer and along grain boundaries in the substrate. After $1000 \mathrm{~h}$ of exposure, the $\mathrm{SiO}_{2}$ phase formed a near-continuous film between the $\mathrm{Cr}_{2} \mathrm{O}_{3}$ and the substrate. The grain boundaries provided fast diffusion paths for oxygen to form additional $\mathrm{SiO}_{2}$ further into the substrate material. Scattered $\mathrm{Cr}_{2} \mathrm{O}_{3}$ phase and $\mathrm{MnS}$ particles of submicron size formed in the substrate. As shown in Fig. 10, the external scale did not contain iron oxide.

\subsubsection{Marathon 50/50Nb}

Marathon $50 / 50 \mathrm{Nb}$, containing $50 \mathrm{wt} . \% \mathrm{Cr}, 48 \mathrm{wt} . \% \mathrm{Ni}$, and $1.75 \mathrm{wt} . \% \mathrm{Nb}$, when exposed in the TVA combustor, was severely corroded (Fig. 11). The suriace was covered with a $100-\mu \mathrm{m}$-thick layer of $\mathrm{CaSO}_{4}$. The second layer was a $150-\mu \mathrm{m}$-thick mixture of oxides and sulfides of the major constituents of the substrate, and $\mathrm{CaSO}_{4}$. The third layer consisted of the products of internal oxidation and sulfidation of the chromium in the substrate matrix. Corrosion attack was generally uniform throughout the entire exposed surface, and preferential attack along grain boundaries was not observed. Depth of maximum penetration was $\approx 250 \mu \mathrm{m}$.

For the Marathon 50/50Nb exposed in the Rocketdyne AFBC, the corrosion morphology (see Fig. 12) was quite different from that obtained by exposure in the TVA AFBC. The external surface was covered with a mixture of oxides and sulfides containing iron, calcium, and chromium. A continuous, $10-\mu \mathrm{m}$-thick $\mathrm{Cr}_{2} \mathrm{O}_{3}$ scale formed between the external scale and the substrate. Internal attack by oxidation and sulfidation of chromium extended $90 \mu \mathrm{m}$ deep. EDS/WDS analyses indicated that $\mathrm{Cr}_{2} \mathrm{O}_{3}$ and $\mathrm{Cr}_{\mathrm{x}} \mathrm{S}$ were the primary corrosion products.

\subsubsection{Nicro 82}

Nicro 82 is a nickel-base filler metal containing $18.7 \mathrm{wt} . \%$ chromium, as shown in Table 1. The surface of the TVA-exposed Nicro 82 was covered with a thick layer of $\mathrm{CaSO}_{4}$ (Fig. 13). The corrosion performance of Nicro 82 is promising compared to that of other materials tested in the same environment. The 5- $\mu \mathrm{m}$-thick oxide scale blocked most of the internal penetration of oxygen and sulfur that occurred in other tested filler materials. This oxide layer consists primarily of the $\mathrm{Cr}_{2} \mathrm{O}_{3}$ phase. A large amount of $\mathrm{MnO}$ was also detected in this layer. Corrosion resistance of Nicro 82, unlike that of other high-Ni alloys such as Marathon 30/50 and Marathon 50/50Nb, was not impaired by its high nickel content (72 wt.\%). However, instability still present at a few locations where internal attack occurred. Maximum oxide penetration was about $85 \mu \mathrm{m}$. Corrosion products included $\mathrm{Cr}_{2} \mathrm{O}_{3}, \mathrm{MnS}$, and $\mathrm{Cr}_{\mathrm{k}} \mathrm{S}$. 

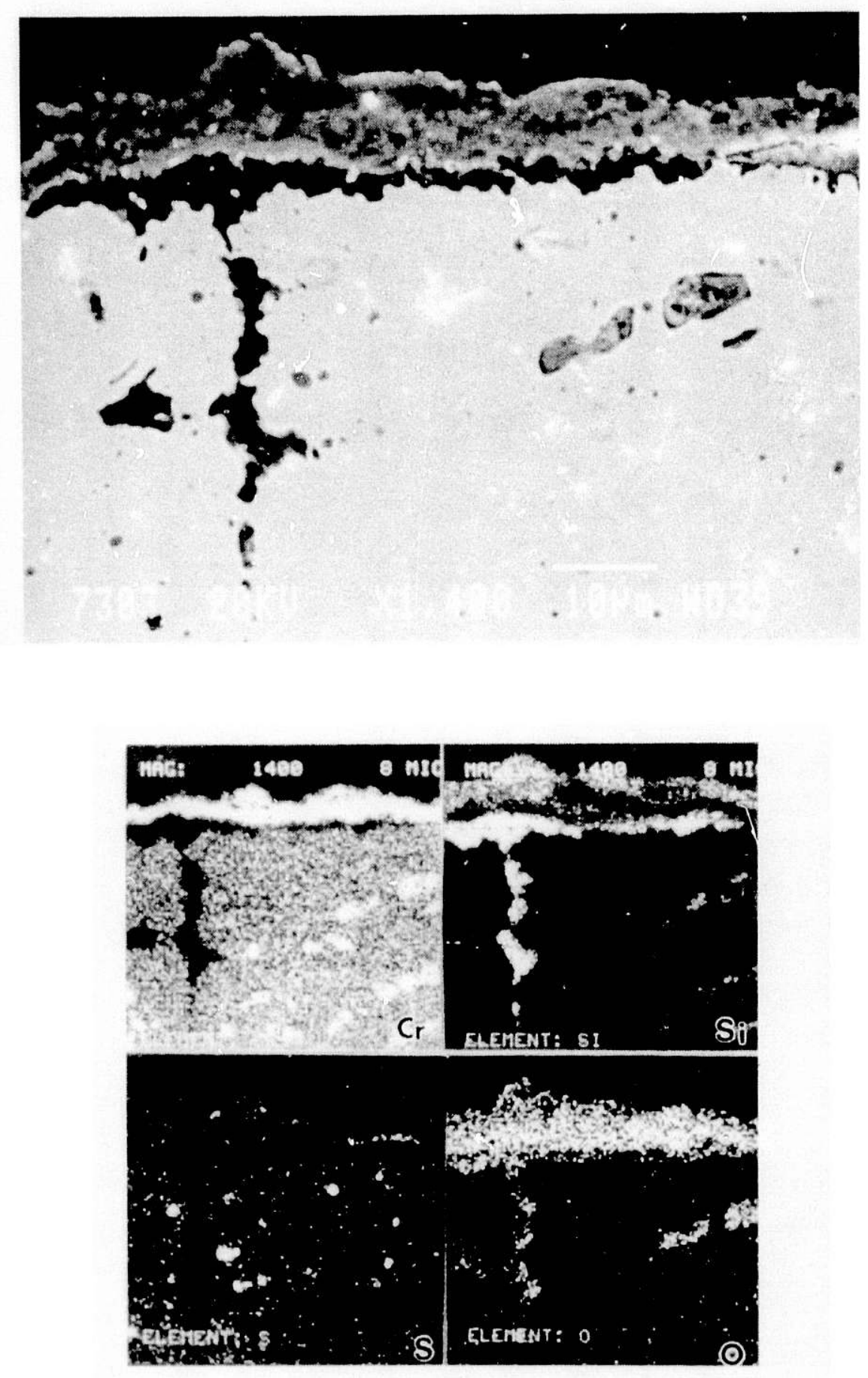

Fig. 10. SEM Micrograph and X-ray Mapping of Marathon 30/50 Exposed in Rocketdyne AFBC 


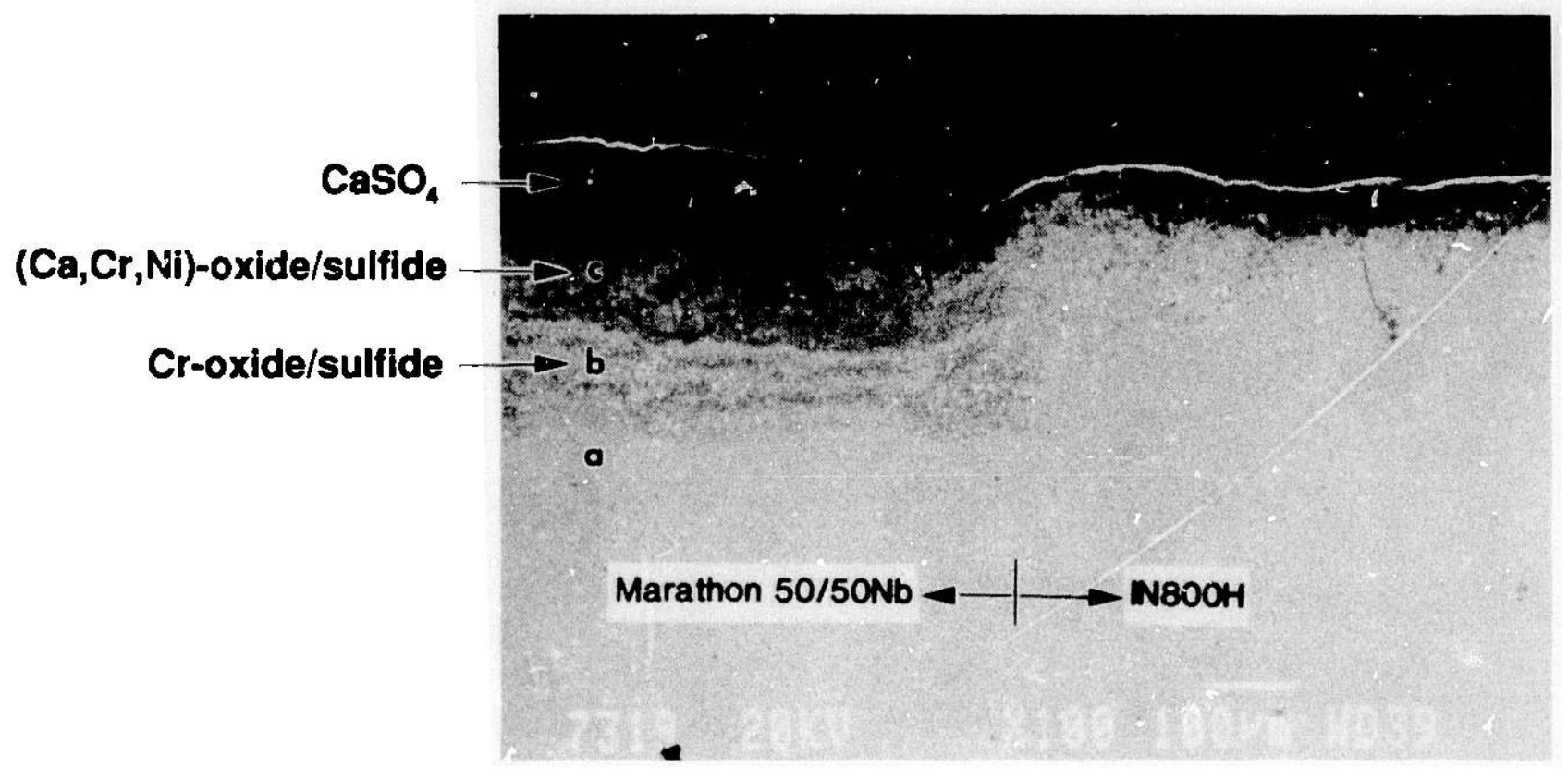

Fig. 11. SEM Micrograph of 50/50Nb Exposed in TVA AFBC 

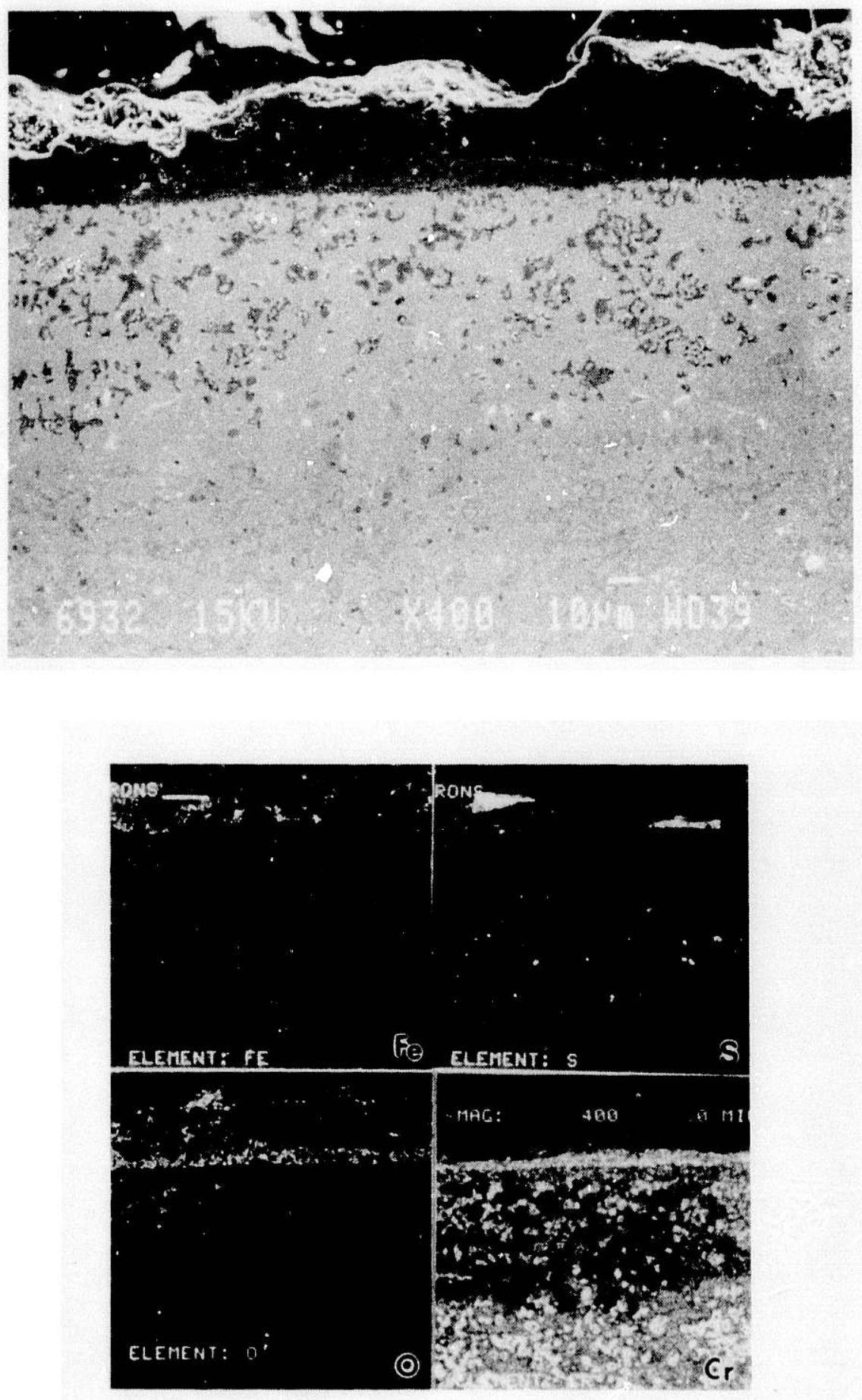

Fig. 12. SEM Micrograph and X-ray Mapping of Marathon 50/50Nb Exposed in Rocketdyne AFBC 


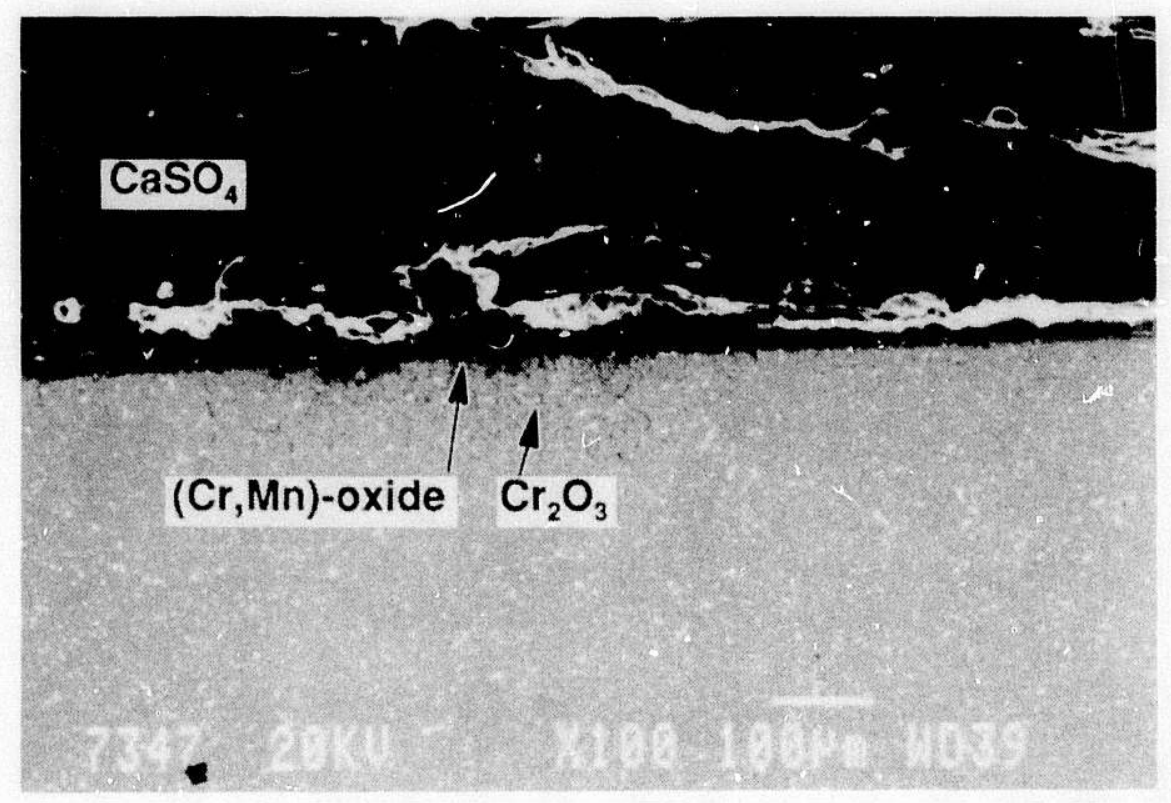

Fig. 13. SEM Micrograph of Nicro 82 Exposed in TVA AFBC

Similar corrosion performance was observed in the Rocketdyne specimens (Fig. 14). A 4- $\mu$ m-thick $\mathrm{Cr}_{2} \mathrm{O}_{3}$ layer formed at the sample surface and appeared to be corrosion-resistant except for a few localized breakdowns that resulted in internal oxidation of the alloy. Some of the internal attacks were clearly associated with $\mathrm{CaSO}_{4}$ deposition. Depth of maximum penetration of internal attack was $\approx 60 \mu \mathrm{m}$.

\subsubsection{Haynes 188}

Cobalt-based Haynes 188 experienced very little corrosion attack when exposed in the TVA facility. As shown in Fig. 15, the sample surface was covered with a thick $\mathrm{CaSO}_{4}$ deposit. A thin (3-5 $\mu \mathrm{m}) \mathrm{Cr}_{2} \mathrm{O}_{3}$ layer formed between the sulfate deposit and the substrate alloy. Minor grain boundary attack was observed. The primary corrosion product, along grain boundaries, was $\mathrm{Cr}_{\mathrm{x}} \mathrm{S}$. Small amounts of $\mathrm{Cr}_{2} \mathrm{O}_{3}$ and $\mathrm{SiO}_{2}$ were also observed around the sulfide phases. The depth of maximum internal attack was $\approx 50 \mu \mathrm{m}$.

Corrosion of the Rocketdyne-exposed specimen was similar to that of the TVA specimen, as shown in Fig. 16. A thin layer of $\mathrm{Cr}_{2} \mathrm{O}_{3}$ scale, $<3 \mu \mathrm{m}$ thick, formed on the sample surface. Internal sulfidation, primarily $\mathrm{Cr}_{\mathrm{x}} \mathrm{S}$, occurred within $30 \mu \mathrm{m}$ of the surface. Sulfide phases were observed along the grain boundary at $\approx 25 \mu \mathrm{m}$ from the surface. $\mathrm{A}$ few $\mathrm{SiO}_{2}$ particles were observed along the $\mathrm{Cr}_{2} \mathrm{O}_{3}$ /alloy interface. 


\subsubsection{RA 333}

The RA 333 weld specimen, containing $25 \mathrm{wt} . \% \mathrm{Cr}$ and $46 \mathrm{wt} . \% \mathrm{Ni}$, suffered serious localized corrosion attack during exposure in the TVA AFBC, as shown in Fig. 17. The specimen surface was covered with a thick layer of combustor deposit mixed with iron oxide. A 20- $\mu \mathrm{m}$-thick $\mathrm{Cr}_{2} \mathrm{O}_{3}$ scale formed at the deposit/substrate interface, and this phase was aiso observed along grain bcandaries. $\mathrm{SiO}_{2}$ formed beneath the $\mathrm{Cr}_{2} \mathrm{O}_{3}$ scale, as shown in the WDS $\mathrm{X}$ - ray mapping, and $\mathrm{Cr}_{\mathrm{x}} \mathrm{S}$ particles were distributed in the substrate region.

The corrosion mechanism of RA 333 in the Rocketdyne AFBC is quite complicated. As shown in Fig. 18, the external layer was composed of a $\mathrm{CaSO}_{4}$ deposit that adhered to the specimen surface. The second layer was predominantly iron oxide mixed with calciun oxide. Below the iron oxide was a layer of $\mathrm{Cr}_{2} \mathrm{O}_{3}$, about 3-5 $\mu \mathrm{m}$ thick. Finally, along the interface between the $\mathrm{Cr}_{2} \mathrm{O}_{3}$ and the substrate alloy, scattered $\mathrm{SiO}_{2}$ particles were identified. Both $\mathrm{Cr}_{2} \mathrm{O}_{3}$ and $\mathrm{SiO}_{2}$ extended further into the substrate along grain boundaries. $\mathrm{Cr}_{x} \mathrm{~S}$ was observed in the substrate matrix in the form of scattered particles of submicron size.

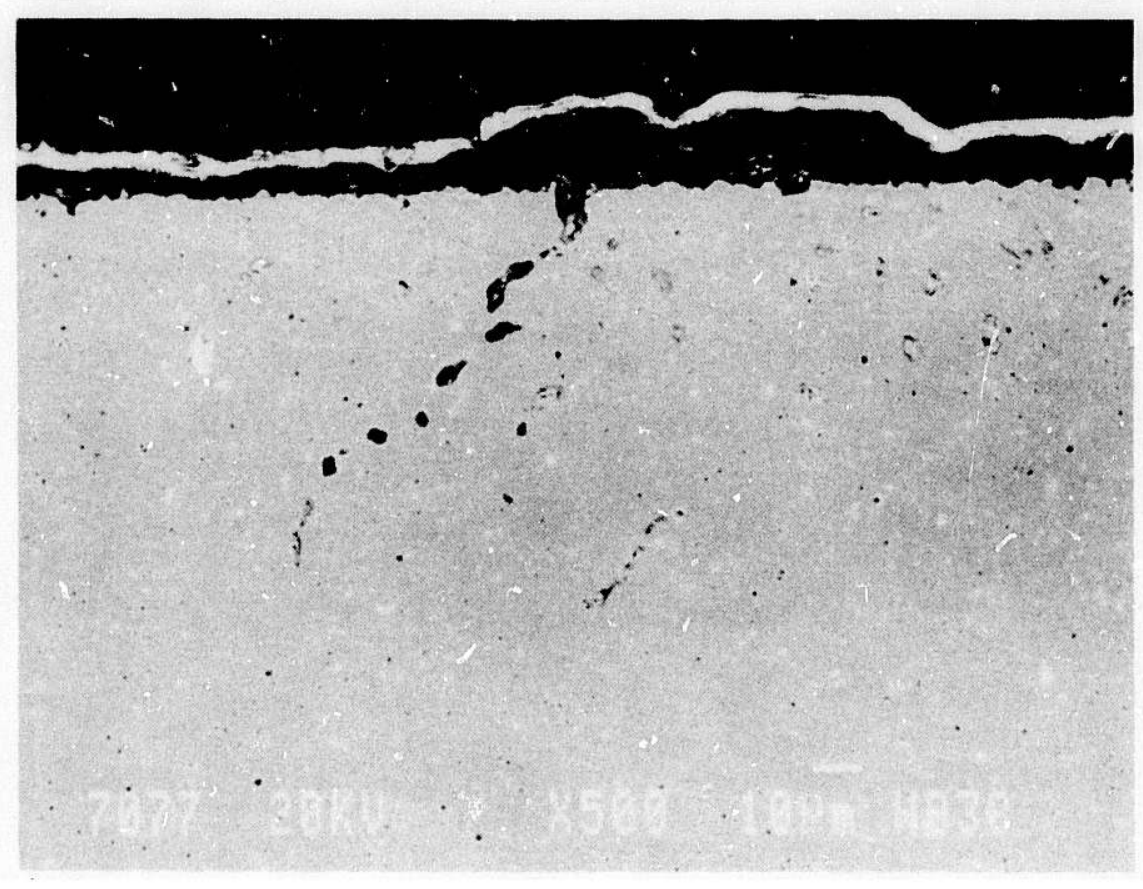

Fig. 14. SEM Micrograph of Nicro 82 Exposed in Rocketdyne AFBC 


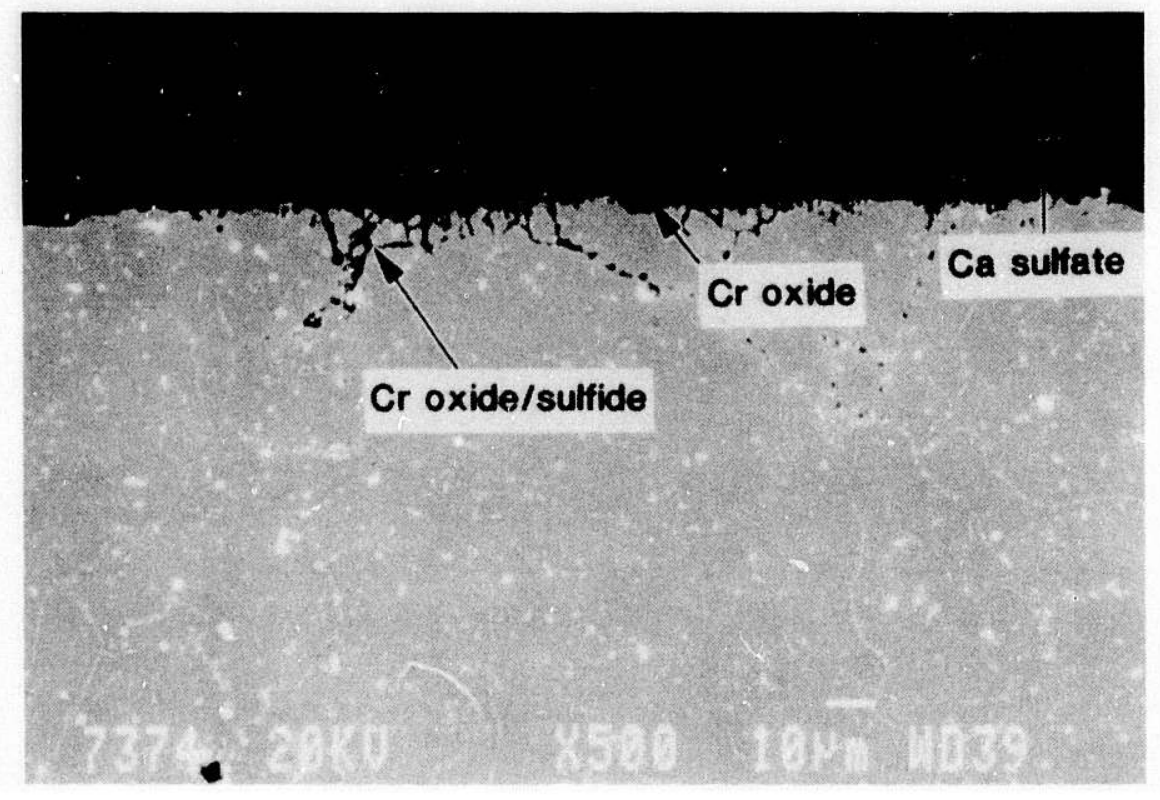

Fig. 15. SEM Micrograph of Haynes 188 Exposed in TVA AFBC

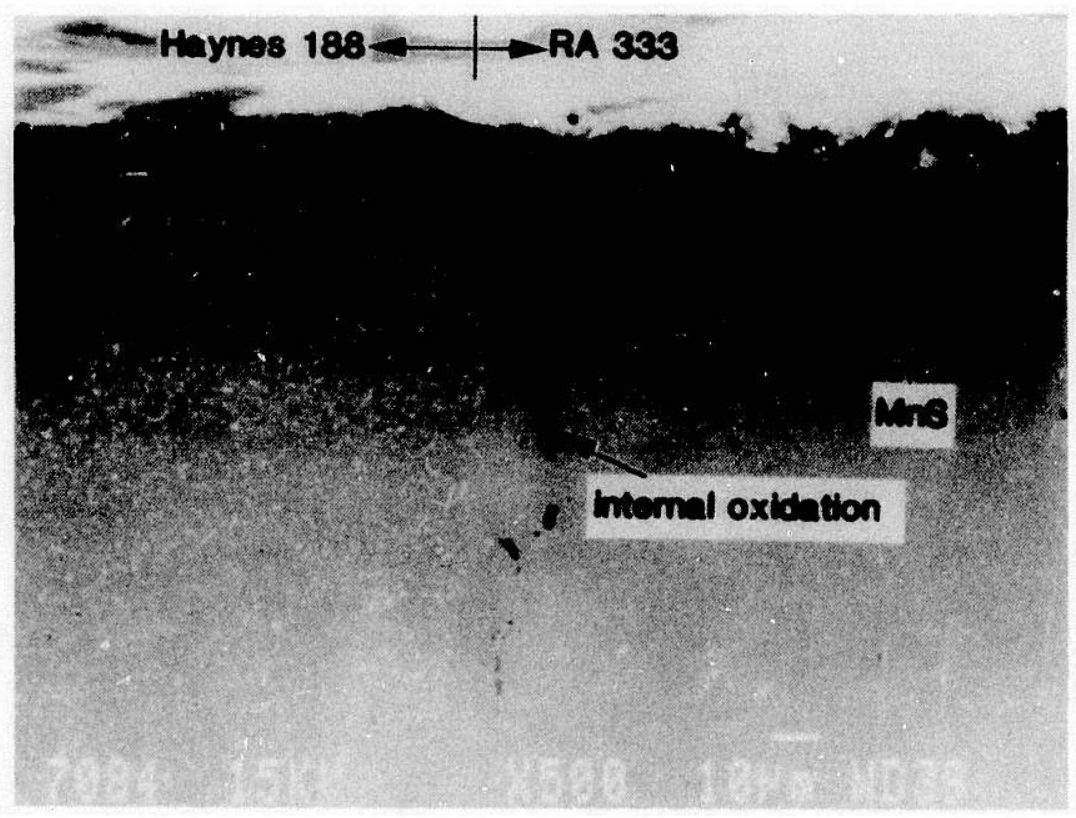

Fig. 16. Weld Interface between Haynes 188 and RA 333 Exposed in Rocketdyne AFBC 

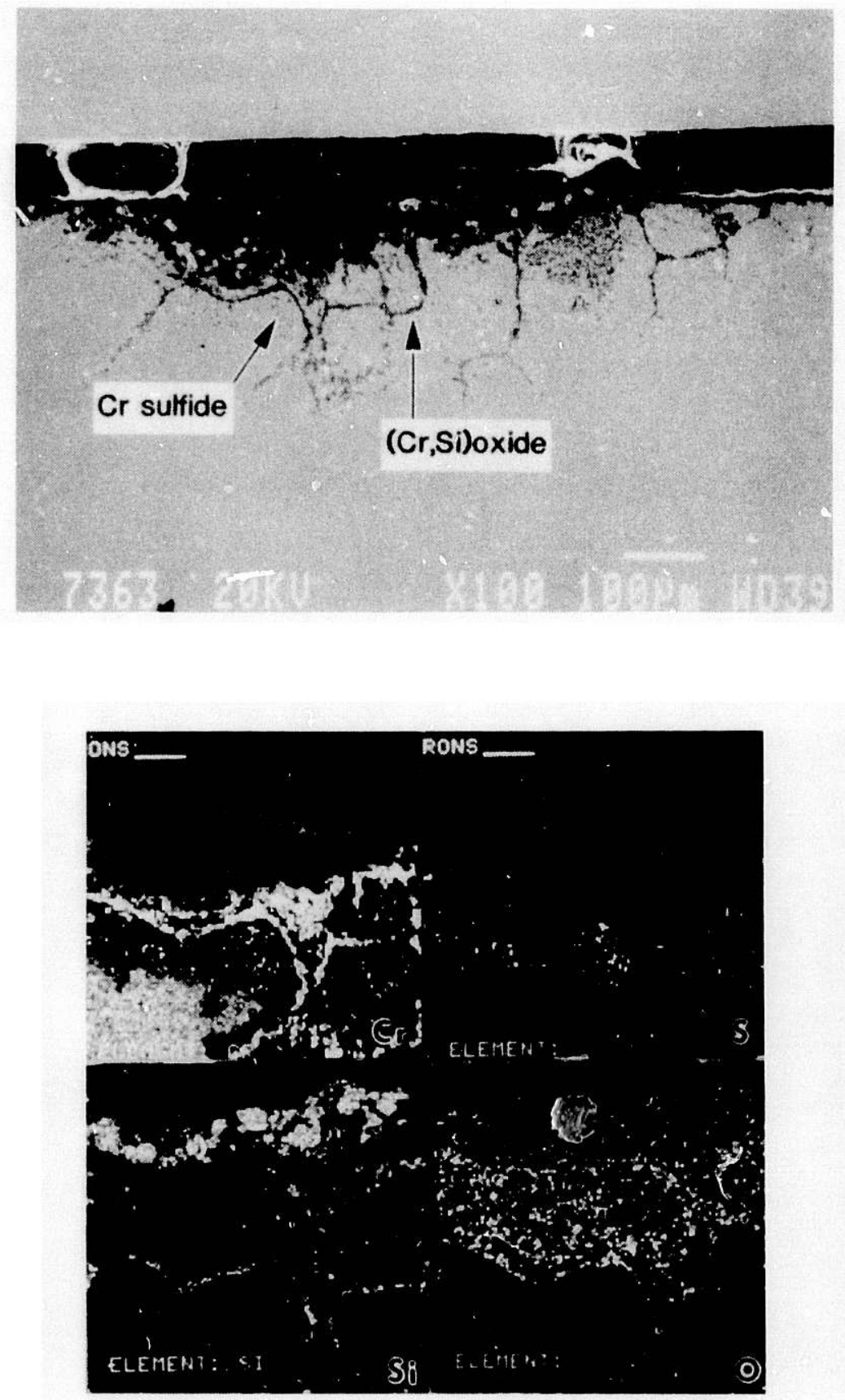

Fig. 17. SEM Micrograph and X-ray Mapping of RA 333 Exposed in TVA AFBC 

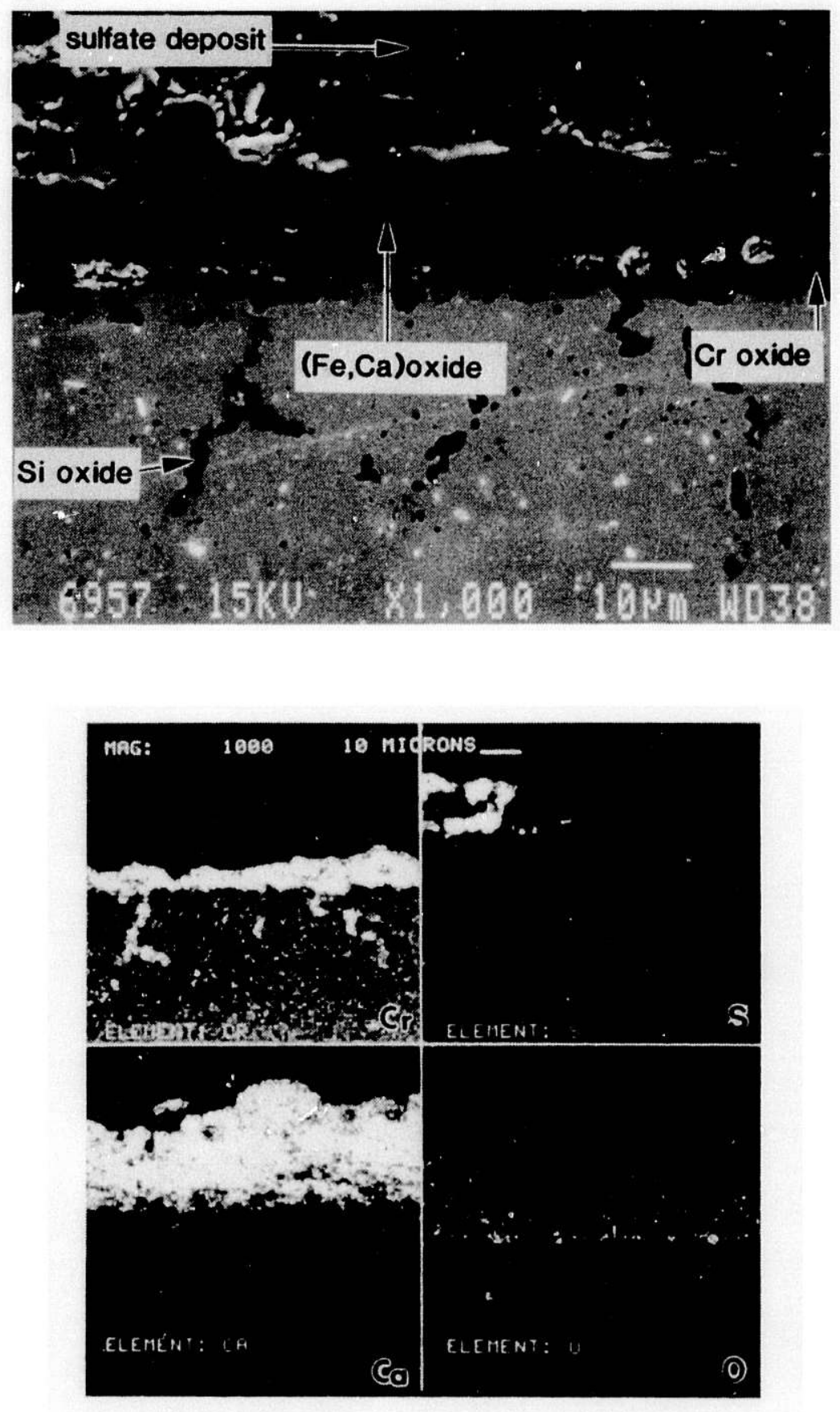

Fig. 18. SEM Micrograph and X-ray Mapping of RA 333 Exposed in Rocketdyne AFBC 


\section{DISCUSSION}

The results of exposing the eight filler materials in the TVA and Rocketdyne AFBCs show various influences of operating conditions, coal/ash chemistry, and alloying elements on the corrosion performance of weldments.

\subsection{CORROSION MORPHOLOGY}

Corrosion performance of the selected filler materials and the substrate material IN800H, after exposure in the TVA and Rocketdyne AFBCs for 1261 and $1000 \mathrm{~h}$, respectively, is summarized in Table 4 and Figure 19. The total corrosion penetration was calculated as the sum of the scale thickness and the depth of the internal attack. In all cases, specimens in the TVA combustor experienced more severe corrosion attack. Except for Nicro 82, the total depth of corrosion penetration of samples exposed in the TVA AFBC was at least twice that of specimens in the Rocketdyne AFBC. The projected linear and parabolic metal recession rates of $0.5 \mathrm{~mm} / \mathrm{yr}$ are superimposed in Fig. 19A. Among all materials tested, only Marathon 25/35R and Haynes 188 had a metal recession rate below $0.5 \mathrm{~mm} / \mathrm{yr}$ in both the TVA and the Rocketdyne AFBCs. The chromium content of the weldment specimen provided the primary corrosion resistance by forming a thin layer of $\mathrm{Cr}_{2} \mathrm{O}_{3}$ at the sample surface. An additional iron oxide layer formed on top of the $\mathrm{Cr}_{2} \mathrm{O}_{3}$ scale for most of the iron-based filler metals (such as the Marathon series and RA 333) when exposed in the TVA facility. Heavy external sulfate deposition was usually associated with this iron oxide layer. The influence of the sulfate deposit will be explained in the following sections. The $\mathrm{Cr}_{2} \mathrm{O}_{3}$ scale did not seem to provide complete protection against corrosion for the materials tested in this study. All of the specimens exhibited some degree of internal oxidation/sulfidation. Even the best performers (Marathon 25/35R and Haynes 188) suffered slight intergranular sulfidation attack. For ultimate corrosion protection in AFBCs, surface modification such as diffusion coating over the entire weldment, including the $\mathrm{HAZ}$, may be required.

\subsection{EFFECT OF ALLOY COMPOSITION}

As shown in Fig. 11, specimens with higher nickel content tend to be more susceptible to corrosion in AFBC environments. Results of the current study agree with those of Sethi et al. ${ }^{6}$ and Klein et al., ${ }^{3}$ which indicated an accelerated corrosion attack of high-nickel filler metals in mixed oxygen-sulfur environments. However, improved corrosion resistance is possible by alloy modification such as a small addition of $\mathrm{Nb}$ or $\mathrm{Mn}$. For Marathon 25/35R, which differs from Marathon 25/35 only in its $\mathrm{Nb}$ content of $1.35 \mathrm{wt} . \%$, there is more than a two-fold reduction in the material recession rate. For the nickel-based Nicro 82 , the 3.9 wt.\% $\mathrm{Mn}$ seemed to promote the formation of $\mathrm{MnO}$ in addition to the $\mathrm{Cr}_{2} \mathrm{O}_{3}$ scale at the surface. The integrity of the oxide scale was significantly improved, which resulted in reduced corrosion attack. For the cobalt-base Haynes 188, which contains 22.77 wt.\% Ni, 22.17 wt.\% $\mathrm{Cr}, 1.67 \mathrm{wt} . \% \mathrm{Fe}$, the substrate material was well protected by a thin layer of $\mathrm{Cr}_{2} \mathrm{O}_{3} \mathrm{scale}$ at the surface. 
Table 4. Summary of Corrosion Attack in TVA and Rocketdyne AFBCs

\begin{tabular}{|c|c|c|c|c|}
\hline \multirow{2}{*}{ Specimen } & \multicolumn{2}{|l|}{ TVA } & \multicolumn{2}{|l|}{ Rocketdyne } \\
\hline & $\begin{array}{l}\text { Scale/Intemal Attack } \\
\qquad(\mu \mathrm{m} / \mu \mathrm{m})\end{array}$ & $\begin{array}{l}\text { Corrosion } \\
\text { Products }\end{array}$ & $\begin{array}{l}\text { Scale/Internal Attack } \\
\qquad(\mu \mathrm{m} / \mu \mathrm{m})\end{array}$ & $\begin{array}{l}\text { Corrosion } \\
\text { Products }\end{array}$ \\
\hline IN800H & $20 / 230$ & $\mathrm{Fe}_{\mathrm{x}} \mathrm{O}, \mathrm{Cr}_{2} \mathrm{O}_{3}, \mathrm{Cr}_{x} \mathrm{~S}$ & $4 / 36$ & $\mathrm{Cr}_{2} \mathrm{O}_{3}, \mathrm{MnS}$ \\
\hline Alloy" $21 / 33$ & $35 / 55$ & $\begin{array}{l}\mathrm{Fe}_{\mathrm{x}} \mathrm{O}, \mathrm{Cr}_{2} \mathrm{O}_{3}, \mathrm{Cr}_{\mathrm{x}} \mathrm{S} \\
\mathrm{SiO}_{2}, \mathrm{MnS}\end{array}$ & $5 / 45$ & $\begin{array}{l}\mathrm{Cr}_{2} \mathrm{O}_{3}, \mathrm{SiO}_{2}, \mathrm{MnS} \\
\mathrm{Cr}_{x} \mathrm{~S}\end{array}$ \\
\hline Alloy* $25 / 35$ & $40 / 100$ & $\begin{array}{l}\mathrm{SiO}_{2}, \mathrm{Cr}_{2} \mathrm{O}_{3}, \mathrm{Cr}_{\mathrm{x}} \mathrm{S} \\
\mathrm{CaS}\end{array}$ & $5 / 45$ & $\mathrm{SiO}_{2}, \mathrm{Cr}_{2} \mathrm{O}_{3}, \mathrm{MnS}$ \\
\hline Alloy" 25/35R & $\mathrm{n} / \mathrm{a}$ & $\mathrm{n} / \mathrm{a}$ & $3 / 0$ & $\mathrm{Cr}_{2} \mathrm{O}_{3}, \mathrm{MnS}$ \\
\hline Alloy $30 / 50$ & $100 / 150$ & $\begin{array}{l}\mathrm{SiO}_{2}, \mathrm{Cr}_{2} \mathrm{O}_{3}, \mathrm{Fe}_{\mathrm{x}} \mathrm{O} \\
\mathrm{Cr}_{\mathrm{x}} \mathrm{S}\end{array}$ & $5 / 80$ & $\mathrm{SiO}_{2}, \mathrm{Cr}_{2} \mathrm{O}_{3}, \mathrm{MnS}$ \\
\hline Alloy" 50/50Nb & $150 / 100$ & $\begin{array}{l}\mathrm{Fe}_{\mathrm{x}} \mathrm{O}, \mathrm{Cr}_{2} \mathrm{O}_{3}, \mathrm{CaS} \\
\mathrm{MnS}, \mathrm{Cr}_{\mathrm{x}} \mathrm{S}\end{array}$ & $10 / 80$ & $\mathrm{Cr}_{2} \mathrm{O}_{3}, \mathrm{MnS}$ \\
\hline Nicro 82 & $5 / 95$ & $\begin{array}{l}\mathrm{Cr}_{2} \mathrm{O}_{3}, \mathrm{MnS}, \mathrm{Cr}_{\mathrm{x}} \mathrm{S} \\
\mathrm{MnO}\end{array}$ & $3 / 70$ & $\mathrm{Cr}_{2} \mathrm{O}_{3}, \mathrm{MnS}, \mathrm{MnO}$ \\
\hline Haynes 188 & $4 / 50$ & $\mathrm{Cr}_{\mathrm{x}} \mathrm{S}, \mathrm{Cr}_{2} \mathrm{O}_{3}$ & $1 / 25$ & $\mathrm{Cr}_{2} \mathrm{O}_{3}, \mathrm{Cr}_{\mathrm{x}} \mathrm{S}, \mathrm{MnS}$ \\
\hline RA 333 & $20 / 250$ & $\mathrm{Fe}_{\mathrm{x}} \mathrm{O}, \mathrm{Cr}_{2} \mathrm{O}_{3}, \mathrm{Cr}_{\mathrm{x}} \mathrm{S}$ & $10 / 50$ & $\mathrm{SiO}_{2}, \mathrm{Cr}_{2} \mathrm{O}_{3}, \mathrm{Cr}_{\mathrm{x}} \mathrm{S}, \mathrm{MnS}$ \\
\hline
\end{tabular}

"Marathon Specialty Alloys. 


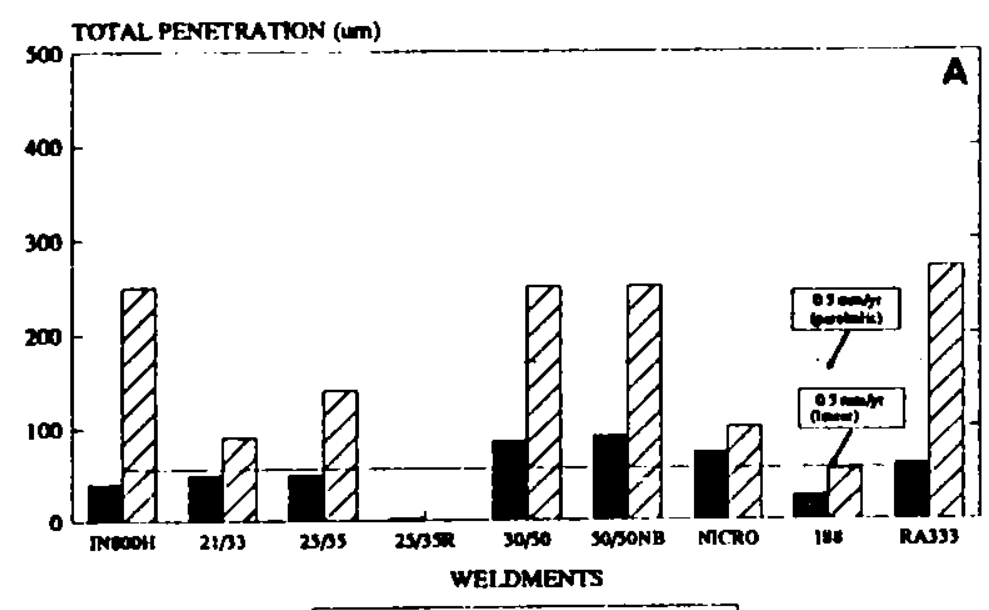

rocketDYNe LUTVA

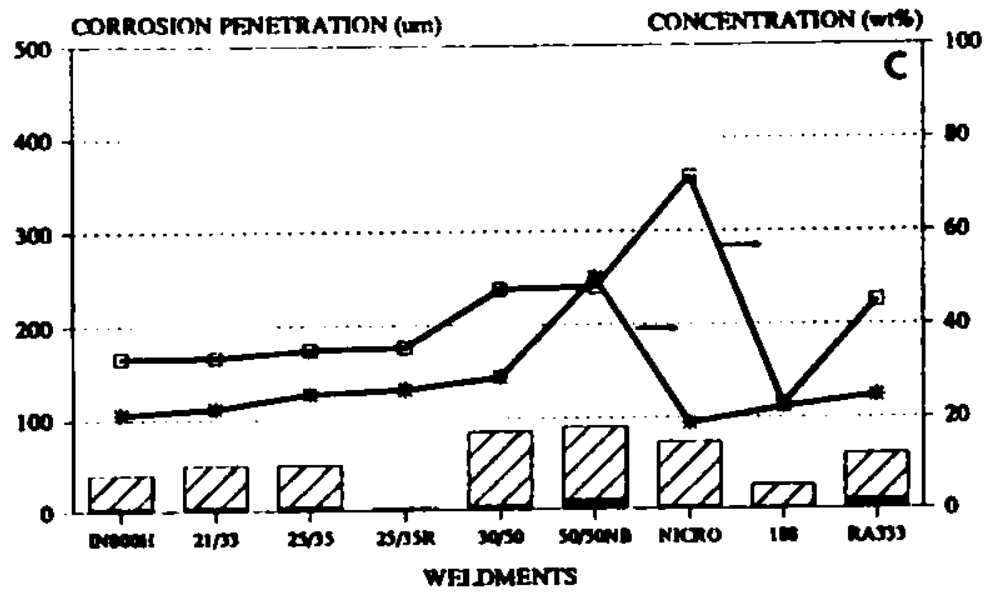

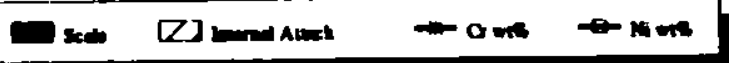

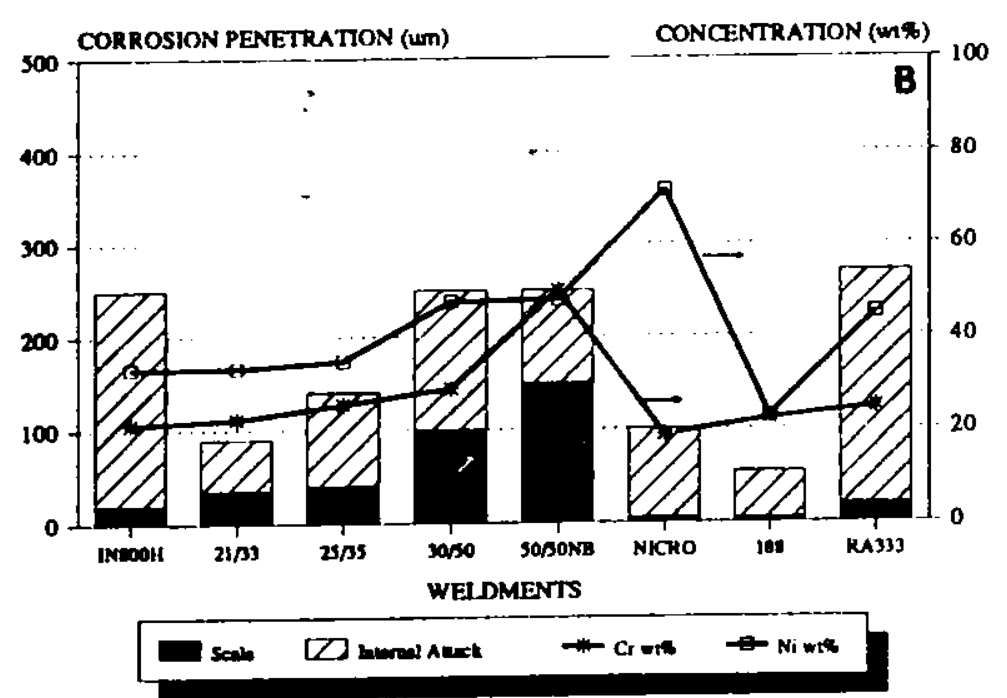

Fig. 19. Summary of Corrosion Attack of Weldments: (A) Total Penetration; (B) Corrosion Attack in TVA AFBC; (C) Corrosion Attack in Rocketdyne AFBC 
The formation of $\mathrm{SiO}_{2}$ in association with $\mathrm{Cr}_{2} \mathrm{O}_{3}$ was observed at the oxide/substrate interface, possibly because the silicon content in the weldment was $\approx 0.8$ to $1.5 \mathrm{wt} . \%$. The interfacial $\mathrm{SiO}_{2}$ layer seems to perform as a diffusion barrier rather than a weakening layer between $\mathrm{Cr}_{2} \mathrm{O}_{3}$ and the substrate alloy. Detachment of $\mathrm{Cr}_{2} \mathrm{O}_{3}$ scale because of the interfacial $\mathrm{SiO}_{2}$ phase was not observed. Consequently, improvement in a protective chromized coating may be possible by the addition of a small amount of silicon. Further study is in progress to determine the amount required and the method of adding silicon to enhance the protective nature of the $\mathrm{Cr}_{2} \mathrm{O}_{3}$ scale.

\subsection{HARDNESS TEST}

Weldment hardness did not change substantially during exposure. Hardness data are plotted in Figs. 20 and 21 as a function of distance from the weld interface in both directions. In general, all of the filler metals had a Vickers hardness reading higher than that of the base metal IN800H. The preexposure hardness data of Nicro 82, Marathon 25/35, Marathon 25/35R, and Marathon 50/50Nb are superimposed on Fig. 20. Except for an $18 \%$ hardness drop for Marathon $25 / 35 \mathrm{R}$, the $\approx 1000$-h exposure in either AFBC did not produce any observable annealing of the weldments. The softening of Marathon 25/35R maybe due to the formation of a thinner (protective) $\mathrm{Cr}_{2} \mathrm{O}_{3}$ layer in contrast to the $\mathrm{CaSO}_{4}$-covered bulky scale that formed on other specimens. Compared with the results obtained at the Rocketdyne facility, the thicker layer of $\mathrm{CaSO}_{4}$ deposit at the surface of the specimen exposed in the TVA AFBC could serve as a thermal barrier that could reduce the annealing effect of the weldments. Haynes 188 and RA 333 showed a hardness reading $\approx 10 \%$ lower in the Rocketdyne AFBC. Besides the difference in $\mathrm{CaSO}_{4}$ coverage, the higher operating temperature in the Rocketdyne facility could also contribute to the lower hardness in Rocketdyne-exposed specimens.

\section{4 $\mathrm{CaSO}_{4}$ DEPOSIT}

This study showed that both deposit composition and the gas-phase environment play significant roles in the development of protective oxide scales on alloy surfaces. ${ }^{5}$ The heavy corrosion attack in the TVA combustor is strongly associated with the bed materials. Interaction between the $\mathrm{CaSO}_{4}$ deposit and substrate materials has been reported.,8

In a fluidized bed combustor, limestone is deliberately added to the bed to absorb the excessive $\mathrm{SO}_{2}$ generated during combustion:

$$
\mathrm{CaO}+\mathrm{SO}_{2}+1 / 2 \mathrm{O}_{2}=\mathrm{CaSO}_{4}
$$

The reaction product, $\mathrm{CaSO}_{4}$, is the major constituent of deposits appearing on the surface of bed components. Fly ash and unreacted $\mathrm{CaO}$ are usually mixed with the sulfate deposit. 

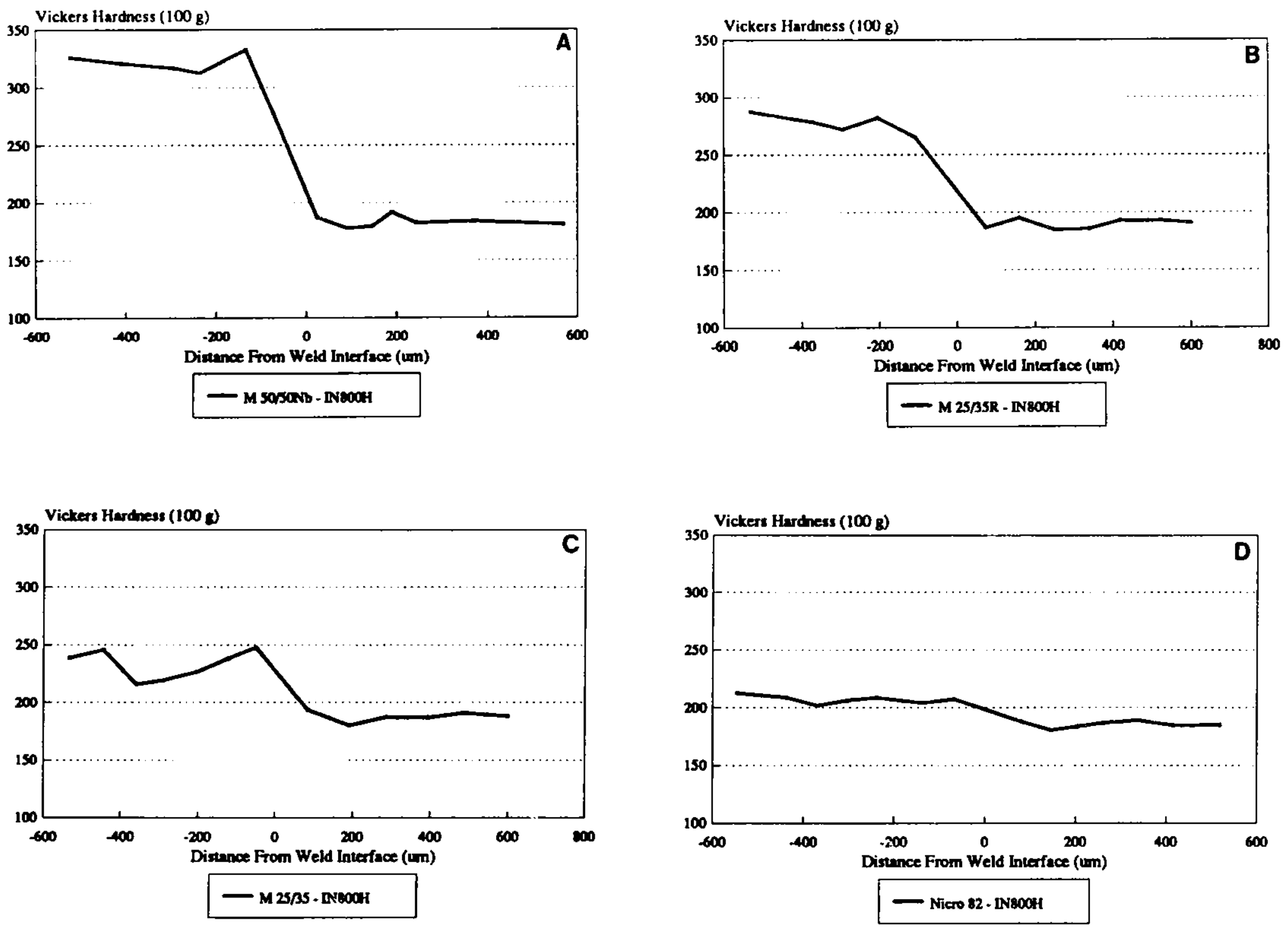

Fig. 20. Pretest Hardness of (A) Marathon 50/50Nb, (B) Marathon 25/35R, (C) Marathon 25/35, and (D) Nicro 82 

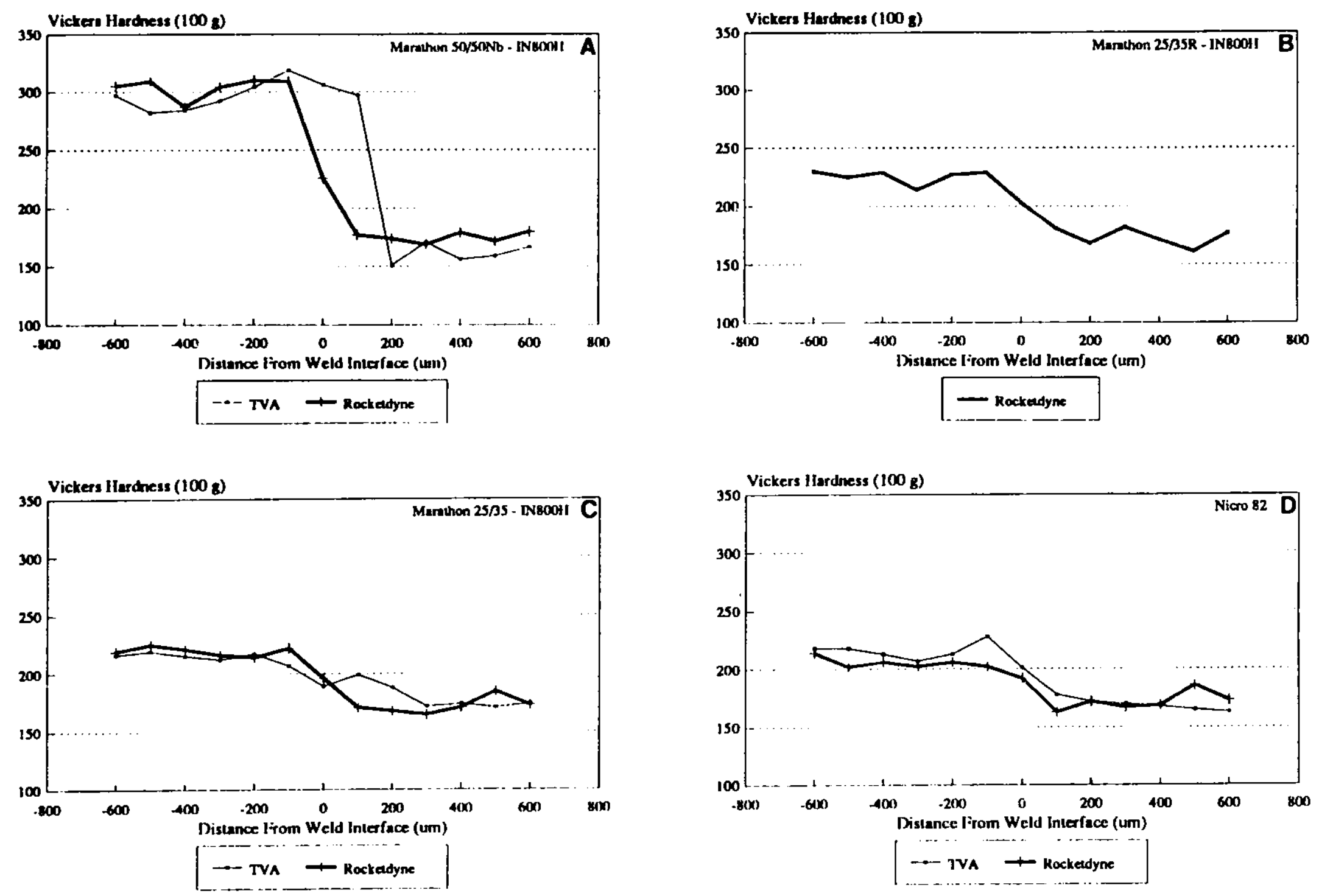

Fig. 21. Posttest Hardness of (A) Marathon 50/50Nb, (B) Marathon 25/35R, (C) Marathon 25/35, (D) Nicro 82, (E) Marathon 21/33, (F) Marathon 30/50, (G) RA 333, and (H) Haynes 188 in TVA and Rocketdyne AFBCs 

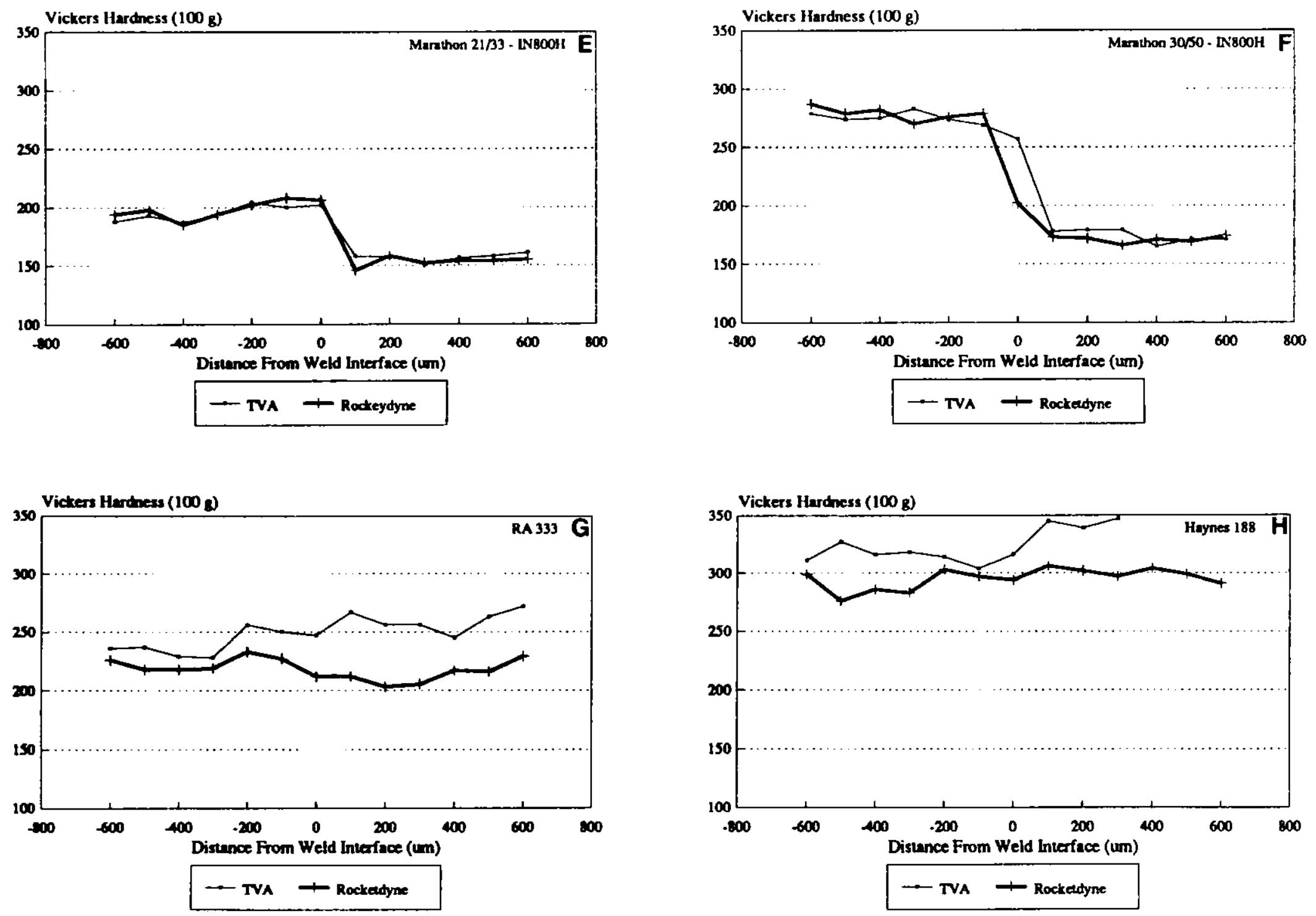

Fig. 21. (Continued) 
Natesan ${ }^{8}$ and Nagarajan et al. ${ }^{9}$ indicated that both $\mathrm{CaS}-\mathrm{CaO}$ and $\mathrm{CaSO}_{4}-\mathrm{CaO}$ deposit mixtures could initiate sulfidation corrosion in both iron-base and nickel-base alloys when the effective oxygen partial pressure of the environment is low. Sulfur release could be governed by the following reactions:

$$
\begin{aligned}
& \mathrm{CaO}+1 / 2 \mathrm{~S}_{2}+3 / 2 \mathrm{O}_{2}=\mathrm{CaSO}_{4} \\
& \mathrm{CaO}+1 / 2 \mathrm{~S}_{2}=\mathrm{CaS}+1 / 2 \mathrm{O}_{2}
\end{aligned}
$$

Many in-bed specimens exhibited a heavy layer of sulfate deposit. The following product could result from a reaction between $\mathrm{CaO}$ and $\mathrm{Cr}_{2} \mathrm{O}_{3}$ scale.

$$
\mathrm{CaO}+\mathrm{Cr}_{2} \mathrm{O}_{3}=\mathrm{CaCr}_{2} \mathrm{O}_{4}
$$

After a DTA test of $\mathrm{CaO}+\mathrm{Cr}_{2} \mathrm{O}_{3}$, the $\mathrm{CaO}$ was totally consumed. X-ray diffractometry confirmed the existence of both $\mathrm{Cr}_{2} \mathrm{O}_{3}$ and $\mathrm{CaCr}_{2} \mathrm{O}_{4}$ in the reaction products. Consequently, the sulfate deposit adhered to the surface of the $\mathrm{Cr}_{2} \mathrm{O}_{3}$ scale via reaction (4). Subsequently, sulfidation attack, as a result of $\mathrm{CaSO}_{4}$ decomposition or $\mathrm{CaS}$ oxidation, was enhanced.

\subsection{COAL/BED CHEMISTRY}

In an FBC system, the chemical environment can fluctuate dynamically. The local equilibrium can alternate among oxidizing, reducing, and possibly sulfidizing conditions. In a $\mathrm{CaO}-\mathrm{CaS}-\mathrm{CaSO}_{4}$ system, as shown in Fig. 22, the equilibrium patial pressures of oxygen and sulfur can be established by the following reactions:

$$
\begin{aligned}
& \mathrm{CaO}+1 / 2 \mathrm{~S}_{2}=\mathrm{CaS}+1 / 2 \mathrm{O}_{2} \\
& \mathrm{CaS}+2 \mathrm{O}_{2}=\mathrm{CaSO}_{4} \\
& \mathrm{CaO}+1 / 2 \mathrm{~S}_{2}+3 / 2 \mathrm{O}_{2}=\mathrm{CaSO}_{4} \\
& \mathrm{CaO}+\mathrm{CaS}+1 / 2 \mathrm{~S}_{2}+7 / 2 \mathrm{O}_{2}=2 \mathrm{CaSO}_{4}
\end{aligned}
$$

Natesan ${ }^{5}$ showed that in the presence of reaction (5) with $\mathrm{SO}_{2}$ in the gas phase, the dominant reaction in the deposit will be sulfation of $\mathrm{CaO}$, which will result in an increase in partial pressures of oxygen and sulfur in the pores of the deposit; however, the $\mathrm{O}_{2}$ partial pressure would still be below that dictated by the $\mathrm{CaO}-\mathrm{CaS}-\mathrm{CaSO}_{4}$ triple point. For reactions (6) and (8), a fairly high suifur partial pressure and low oxygen partial pressure in the deposit/alloy interface can be established. Consequently, the alloy will undergo sulfidation 
attack, and nickel sulfide and iron oxide will be the reaction product phases. However, in the presence of reaction (7) with $\mathrm{SO}_{2}$ in the gas phase, the dominant reaction in the deposit will be sulfation of $\mathrm{CaO}$ to $\mathrm{CaSO}_{4}$, which can decrease the sulfur partial pressure in the pores of the deposit material; thus, the alloy will tend to be oxidized. $\mathrm{A} \mathrm{Cr}_{2} \mathrm{O}_{3}$ layer will form preferentially at the deposit/alloy interface. As shown in Table 4, iron oxide was present in most of the weldment specimens exposed in the TVA AFBC environment. In the Rocketdyne facility, the $\mathrm{Cr}_{2} \mathrm{O}_{3}$ scale was the primary corrosion product, while iron oxide was not observed. This could account for the excessive corrosion attack on the weldments exposed in the TVA facility. In other words, the shift of chemical equilibrium in the TVA combustor favors sulfidation attack rather than formation of $\mathrm{Cr}_{2} \mathrm{O}_{3}$ on a weldment surface. In addition, the iron oxide had a porous microstructure that trapped the sulfate deposit quite easily. Therefore, when exposed in the TVA environment, the oxide $\mathrm{FeO} / \mathrm{Fe}_{2} \mathrm{O}_{3}$ formed preferentially at an early stage. Subsequently, the more stable $\mathrm{Cr}_{2} \mathrm{O}_{3}$ scale formed as a sublayer between the iron oxide and the substrate alloy. The porosity of the iron oxide scale provides a fast diffusion path for the oxidants, such as oxygen and sulfur, from the gaseous environment and the $\mathrm{CaSO}_{4} / \mathrm{CaO}$ deposit to contact the underlying $\mathrm{Cr}_{2} \mathrm{O}_{3}$ scale or bare substrate metals directly.

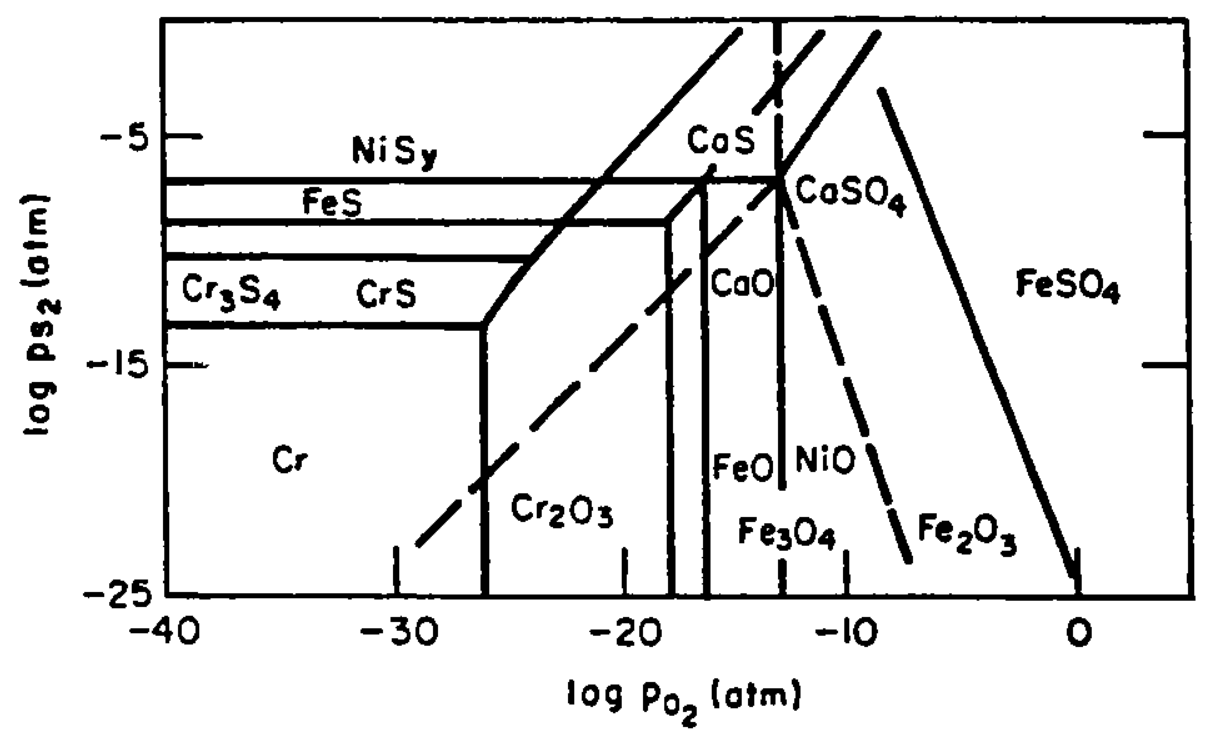

Fig. 22. Stability Diagram of CaO-CaS-CaSO ${ }_{4}$ System Superimposed on an Oxygen-sulfur Thermochemical Diagram Depicting Regions of Stability of Various Oxide and Sulfide Phases at $840^{\circ} \mathrm{C}$ 
Sethi et al. ${ }^{6}$ and Kalmanovitch et al. ${ }^{10}$ reported some influence of feedstock and bed chemistry on the corrosion behavior of the support and transport components in AFBCs. The coal analyses from both AFBC facilities are provided in Table 3. Kentucky coal (Warrior and Sarpy Creek) was used in the TVA AFBC and Illinois \#6 was used in the Rocketdyne facility. The Sarpy Creek coal contained twice as much moisture as the Illinois \#6 coal. The Warrior coal contained more sulfur than the Illinois \#6 coal. Differences in coal chemistry may also have influenced the variations in the corrosion performance of weldments, but the data from the present study are not sufficient to quantify the effect.

\subsection{HEA'T-AFFECTED ZONE}

In most of the exposed specimens, the heat-affected zone (HAZ) generated by the welding process did not induce accelerated corrosion attack. Cold cracking or microfissures were not observed. The only case of HAZ-induced attack was observed in the RA 333 weldment, which was welded to the Haynes 188 and exposed in the Rocketdyne AFBC (Fig. 16). The maximum corrosion penetration in bulk RA 333 exposed in the Rocketdyne AFBC was $60 \mu \mathrm{m}$, as shown in Fig. 19. However, corrosion attack along the weld interface penetrated $130 \mu \mathrm{m}$ into the substrate. Microstructural change and solute redistribution during the welding process could be responsible for the increased attack along the HAZ. However, this is only an isolated case, and similar phenomena were not observed in other weldment specimens.

\section{SUMMARY}

Due to differences in AFBC operating conditions, coal/bed chemistry, and alloying elements in the weldments, the weldment specimens revealed different corrosion behavior upon exposure in the TVA and Rocketdyne fluidized-bed combustors. Among eight tested filler metals, the $\mathrm{Nb}$-modified Marathon 25/35R and the cobalt-base Haynes 188 experienced the least corrosion attack in both test facilities. However, none of the tested materials remained completely corrosion-free after $1000 \mathrm{~h}$ of exposure. For ultimate corrosion resistance in AFBC atmospheres over long operating periods, surface modification may be needed to improve corrosion performance while retaining the mechanical properties of the substrate alloys. The iron- base weldments with higher $\mathrm{Ni}$ content appeared to be more susceptible to corrosion attack in AFBC environments. However, modification of alloys by adding a small amount of $\mathrm{Nb}$ or $\mathrm{Mn}$ could improve their corrosion resistance.

The major corrosion attack observed after AFBC exposures was caused by internal oxidation and sulfidation beneath the external oxide scale. The bed deposit adhered to the specimen surface and thus played a key role in the overall material breakdown in AFBCs. Due to interactions between the $\mathrm{CaSO}_{4} / \mathrm{CaO}$ deposit and the chromia and iron oxide scales, the bed deposit tended to be trapped on the specimen surface. Subsequent sulfate decomposition enhanced the internal oxidation/sulfidation under the otherwise protective $\mathrm{Cr}_{2} \mathrm{O}_{3}$ scale.

Primary corrosion resistance of the weldment specimens relied on the formation of a compact and continuous $\mathrm{Cr}_{2} \mathrm{O}_{3}$ scale on the specimen surface to block further reaction between the substrate elements and the oxidants. Once the integrity of this protective layer 
was disturbed by mechanical failure or chemical interactions with deposit and/or gas phases constituents, nonprotective oxidation/sulfidation ensued, leading to substantial internal penetration of sulfur in the substrate alloy.

Results of the hardness tests indicated that prolonged annealing in AFBC environments did not cause significant softening of the materials. The microstructural analysis did not reveal any evidence of mechanical failure around weld interface or HAZs.

\section{ACKNOWLEDGMENTS}

This work was supported by the U.S. Department of Energy, Office of Conservation and Renewable Energy and Office of Fossil Energy, Advanced Research and Technology Development Materials Program, under Contract W-31-109-Eng-38. The authors are grateful for the assistance of ETEC and TVA for exposure of specimen racks/probes in the two fluidized bed combustors. The authors appreciate the assistance of D. L. Rink, who conducted the metallographic and microscopic analyses of the exposed specimens.

\section{REFERENCES}

1. K. Natesan, S. A. Miller, and W. Podolski, An Assessment of the Performance of Heat Exchanger Materials in Fluidized Bed Combustors, Argonne National Laboratory Report ANL-86-42 (Feb. 1987).

2. V. K. Sethi, D. Robinson-Wilson, P. Ganesan, A. A. Sagues, and R. Q. Vincent, Corrosion Testing Program at the TVA's 20 MW AFBC Pilot Plant, CORROSION/84 Paper No. 90, NACE, Houston (1984).

3. A. Klein, K. Natesan, and W. Podolski, The Atmospheric Fluidized-Bed Cogeneration Air Heater Experiment, Proc. 10th International Conf. on Fluidized Bed Combustion, San Francisco, Vol. 2, p. 1319 (1989).

4. K. Natesan, High-Temperature Corrosion in Coal Gasification Systems, CORROSION, Vol. 41, No. 11, pp. 646-655 (1985).

5. K. Natesan, Corrosion of Heat Exchanger Materials in the Presence of FBC Deposits, Proc. Performance of High Temperature Materials in Fluidized Bed Combustion Systems and Process Industries, ASM, Cincinnati, p. 57 (1987).

6. V. K. Sethi, D. R. Wilson, and R. Q. Vincent, Corrosion of Uncooled Materials in AFBCs-Feedstock Effects, CORROSION/89, Paper No. 536, NACE, Houston (1989). 
7. P. J. Ficalora, Hot Corrosion Reactions of Calcium Sulfate with $\mathrm{Cr}, \mathrm{Ni}, \mathrm{Co}, \mathrm{Fe}$, and Several Alloys, Oak Ridge National Laboratory Report ORNL/TM-8735 (1983).

8. K. Natesan, Role of FBC Deposits in the Corrosion of Heat Exchanger Materials, High Temperature Technology, 4, 193 (1986).

9. V. Nagarajan, R. D. Smith, and I. G. Wright, Influence of Solid-State CaS-CaO-CaSO Deposits on Corrosion of High-Temperature Alloys in Simulated FBC Environments, Oxidation of Metals, Vol. 31, Nos. $3 / 4$ (1989).

10. D. P. Kalmanovitch, D. R. Hajicek, and M. D. Mann, Corrosion and Erosion in a Fluidized Bed Cumbustor: Effect of Bed Chemistry, CORROSION/89, Paper No. 547, NACE, Houston (1989). 